\author{
(online) $=$ ISSN $2285-3642$ \\ ISSN-L = 2285 - 3642 \\ Journal of Economic Development, Environment and People \\ Volume 9, Issue 1, 2020 \\ URL: http://jedep.spiruharet.ro \\ e-mail: office jedep@spiruharet.ro
}

\title{
Techno-economic study of BIPV in typical Sahara region in Algeria.
}

\author{
Khencha Khadidja ${ }^{10}$, Biara Ratiba Wided ${ }^{1}$ and Belmili Hocine ${ }^{2}$ \\ ${ }^{1}$ ARCHIPEL Laboratory, Department of Architecture, Faculty of Technology, University of TAHRI Mohamed- \\ Bechar, Independence Street B.P 417, 08000 Bechar-Algeria. \\ ${ }^{2}$ Solar Equipment Development Unit, UDES, Renewable Energy Development Center, CDER, 42415 Tipaza, \\ Algeria.
}

Abstract. Building in urban areas in the Sahara region is confronted with two main issues: (i) the climate change and (ii) the energy consumption. In order to deal with the latest issues, experts want to focus all their efforts in the use of renewable energy, and most particularly solar energy that is widely available at the Sahara. In this work, we first analyzed the proposed works related to both environmental impact and integration of solar energy in the building. Secondly, we have accurately defined the new concept of Building Integrated Photovoltaic (BIPV), its advantage to minimize the building energy consumption, and its role to reduce greenhouse gas emissions and greenhouse effect due to fossil fuels. Thirdly, we have carried out a comprehensive survey related to benefits, techniques, and criteria affecting the energy efficiency of using BIPV and its advantages over glazing. To be clearer, we have selected as a case of study of a contemporary building covered by standard glazing and replaced by BIPV located in a Sahara region in Algeria. Moreover, the point of view of urban architectural, environmental, and energy economy, has been well investigated. As a result, using BIPV in this specific region of a hot climate has to be a dominant idea to reduce both energy consumption and economical budget.

Keywords: BIPV, Energy Economy, Sahara region, solar energy, Aesthetic, Architectural design.

JEL Codes: $\mathrm{O3}$

How to cite: KHENCHA, K., BIARA, R.W., \& BELMILI, H. (2020). Techno-economic study of BIPV in typical Sahara region in Algeria. Journal of Economic Development, Environment and People, 9(1), 27-57.doi: http://dx.doi.org/10.26458/jedep.v9i1.654 
(online) $=$ ISSN $2285-3642$

ISSN-L = 2285 - 3642

Journal of Economic Development, Environment and People

Volume 9, Issue 1, 2020

URL: http://jedep.spiruharet.ro

e-mail: office jedep@spiruharet.ro

\begin{tabular}{|c|c|c|c|c|c|}
\hline ABRV & Explanation & Unit & ABRV & Explanation & Unit \\
\hline \multirow[b]{2}{*}{$\mathbf{P}$} & \multirow[b]{2}{*}{ Power } & \multirow[b]{2}{*}{ (Wc) } & Ta & Ambient temperature & $\left({ }^{\circ} \mathrm{C}\right)$ \\
\hline & & & PR & Performance index & (\%) \\
\hline \multirow{2}{*}{$A_{p v g}$} & \multirow[t]{2}{*}{ The surface of PV generator } & \multirow[t]{2}{*}{$\left(m^{2}\right)$} & RHD & Diffused horizontal irradiation, & $\left(\mathrm{Wh} / \mathrm{m}^{2}\right)$ \\
\hline & & & RHDR & Direct horizontal irradiation, & $\left(\mathrm{Wh} / \mathrm{m}^{2}\right)$ \\
\hline \multirow[t]{2}{*}{$\eta_{p v g}$} & \multirow[t]{2}{*}{ The efficiency of conversion } & & ECH & $\begin{array}{l}\text { Daily energy consumed by the } \\
\text { load }\end{array}$ & (Wh) \\
\hline & & & EC & Energy consumed per day & $(\mathrm{Wh} / \mathrm{d})$ \\
\hline \multirow{2}{*}{$\eta_{r}$} & \multirow{2}{*}{$\begin{array}{l}\text { Photovoltaic module reference } \\
\text { efficiency }\end{array}$} & & RID & Diffused inclined irradiation & $\left(\mathrm{Wh} \mathrm{m}^{2}\right)$ \\
\hline & & & RHG & Global Horizontal Radiation & $\left(\mathrm{W} / \mathrm{m}^{2}\right)$ \\
\hline \multirow[t]{3}{*}{ B } & \multirow{3}{*}{$\begin{array}{c}\text { Temperature coefficient which } \\
\text { supposed constant for silicon solar } \\
\text { cells. }\end{array}$} & & Ic & Clarity index & \\
\hline & & & Vmno & $\begin{array}{l}\text { Nominal voltage. of the } \\
\text { module }\end{array}$ & (V) \\
\hline & & & Vinst & Installation voltage & (V) \\
\hline \multirow{2}{*}{$T_{\text {cref }}$} & \multirow[t]{2}{*}{ Reference solar cell temperature } & \multirow[t]{2}{*}{$\left({ }^{\circ} \mathrm{C}\right)$} & Vv & Wind speed & $(\mathrm{m} / \mathrm{s})$ \\
\hline & & & Lat & Latitude & $\left({ }^{\circ} \mathrm{N}\right)$ \\
\hline \multirow{2}{*}{$G_{i r}$} & \multirow[t]{2}{*}{ Global solar irradiation } & \multirow[t]{2}{*}{$\left(\mathrm{W} / \mathrm{m}^{2}\right)$} & Lon & Longitude & $\left({ }^{\circ} \mathrm{E}\right)$ \\
\hline & & & CB & Battery cost & \multirow{16}{*}{$€$} \\
\hline$T_{c}$ & Solar cell temperature & $\left({ }^{\circ} \mathrm{C}\right)$ & TC & Total cost & \\
\hline NB & Total number of batteries & & MC & Module cost & \\
\hline NBP & Number of batteries in parallel & & CO & Indirect cost & \\
\hline NMS & Number of modules in series & & GCPV & PV generator cost & \\
\hline NMP & Number of modules in parallel & & CS & Cost of the stockyard & \\
\hline SF & Security Factor & & Creg & Cost of the regulator to install & \\
\hline NBP & Number of batteries in parallel & & Cond & Inverter cost, if needed & \\
\hline Cacc & Capacity of the storage battery. & $(\mathrm{Ah})$ & $\mathbf{T}$ & System life & \\
\hline Acel & Module area & $\left(m^{2}\right)$ & TCLF & $\begin{array}{l}\text { Total estimated cost for a } \\
\text { expected life of the facility }\end{array}$ & \\
\hline ADC & Average daily consumption & $\left(\mathrm{Wh} / \mathrm{m}^{2}\right)$ & Cons & $\begin{array}{c}\text { Annual consumption of the } \\
\text { system }\end{array}$ & \\
\hline Ic & Clarity index & & RCB & Replacement cost of Batteries & \\
\hline Ir & Irradiation Incident & $\left(\mathrm{W} / \mathrm{m}^{2}\right)$ & \multirow[t]{2}{*}{ COM } & \multirow{2}{*}{$\begin{array}{c}\text { Cost of operation and } \\
\text { maintenance }\end{array}$} & \\
\hline \multirow[t]{2}{*}{ Unom } & \multirow[t]{2}{*}{ Rated Voltage } & \multirow[t]{2}{*}{ (V) } & & & \\
\hline & & & \multirow{2}{*}{$C_{\mathrm{PVkWh}}$} & \multirow{2}{*}{$\begin{array}{l}\text { The cost price in } \mathrm{kWh} \text { of the } \\
\text { PV system }\end{array}$} & \\
\hline A & Sun height & $\left({ }^{\circ}\right)$ & & & \\
\hline $\mathbf{U}$ & Voltage of the installation & (V) & \multirow[b]{2}{*}{$\rho$} & \multirow[b]{2}{*}{ Solar reflectivity or Albedo } & \\
\hline RHG & Global Horizontal Radiation, & $\left(\mathrm{W} / \mathrm{m}^{2}\right)$ & & & \\
\hline
\end{tabular}




\author{
(online) $=$ ISSN $2285-3642$ \\ ISSN-L = $2285-3642$ \\ Journal of Economic Development, Environment and People \\ Volume 9, Issue 1, 2020 \\ URL: http://jedep.spiruharet.ro \\ e-mail: office jedep@spiruharet.ro
}

\title{
1. Introduction
}

\subsection{Background and motivation}

In the last century, the consumption of a large part of the global energy demand in construction has been recorded, energy consumption accounts for about $40 \%$ of total global energy consumption, with much of this energy being directed to heating and cooling residential and commercial buildings (Dabaieh \& Elbably, 2015). Accelerated reconstruction in the world has caused significant pollution, especially in developed countries, as a result of carbon dioxide emissions due to the large proportion of industrialization in these countries. In addition, due to the increase in population density. The carbon dioxide emission was about $39 \%$ for the United States, 36\% in Europe and 20\% for China (Eicker, 2014). The researchers have been paying tremendous efforts. The improvement of buildings' energy efficiency is of crucial importance to decrease buildings' energy needs, and therefore the amount of fossil fuels used to supply the required energy. However, the global consumption of fossil fuels (energy polluting energy) can be reduced by exploiting a variety of renewable energies and incorporating them into buildings to provide heat and electricity.

Currently, rapid population growth, as a result of urbanization, development and the associated urban and construction transformation have led to higher environmental costs for the economy (Kendirli, Unal, \& Basaran, 2014).A lot of efforts are dedicated to efficiently reduce energy demands in buildings and creates new opportunities for the use of renewable energy resources. Indeed, by 2030 , it is expected that $35 \%$ of global electricity in the world will be generated from renewable energy. Due to its abundant nature, economical characteristic, and clean feature, solar energy is considered as the most productive energy (i.e., provides an electrical power up to $1.8 \times 1011 \mathrm{MW}$ ) compared to all renewable energy resources (Lewis \& Nocera, 2006). It is demonstrated that the reception of solar energy in the terrestrial globe during a less than an hour would be sufficient to cover a full world energy year (Bonomo, Chatzipanagi, \& Frontini, 2015). For a deep understanding, the world required daily electrical energy approximately 15 TW (i.e., $151012 \mathrm{~W}$ ), which is considered as 104 times smaller than the electrical solar energy that can be produced on the earth (Jelle, 2016). Therefore, since non-renewable resources of energy are not a long-term solution, it is imperative to change the type of energy supply. As a free source of unlimited energy, the sun has a preponderant role to play the role of this supply. During the last decade, the integration of Photovoltaic (PV) in the building is becoming a reality and attracts the interest of researchers working on solar energy. For instance, in some EU countries, directives and subsidies are fully allocated for the use of renewable energies with the aim to minimize fossil fuels.

When PV panels are integrated into a building facade, they can be considered as building materials allowing electricity generation. This concept is known as Building Integrated PV (BIPV), which is a multifunctional intelligent system used composed of solar modules intercepting solar rays and convert them into clear green electricity. BIPV can be installed in a building in different places, such as facades, roof, pitched roofs, flat roofs, windows, shading elements, balconies louvers, and tiles (e.g., solar tiles) (Wilson \& Young, 1996) (c.f., Fig. 1). Indeed, about $80 \%$ of the BIPV's installations are roof-mounted and the remaining ones $20 \%$ are mounted on the facade in which they act as a rain screen (Hestnes, 1999). Due to the recent advancements in terms of solar energy technology, BIPV cannot only be perfectly integrated into buildings, but also can provide more aesthetic architectural expression, such as coherent variations in proportions, surfaces, models, colors, and textures (Tian et al., 2018). Also, BIPV can be composed of semi-transparent PV panels that can be successfully integrated into architectural glazing. For instance, the work in (Jelle, Breivik, \& Røkenes, 2012) described the different materials for BIPV, which are available on the market along with its applications. The authors in (Schuetze, 2013) presented the best BIPV products, their different properties, 

2015), a detailed description of BIPV, its available materials, and its applications, are presented. Moreover, the authors selected a case study in a city in Dubai.

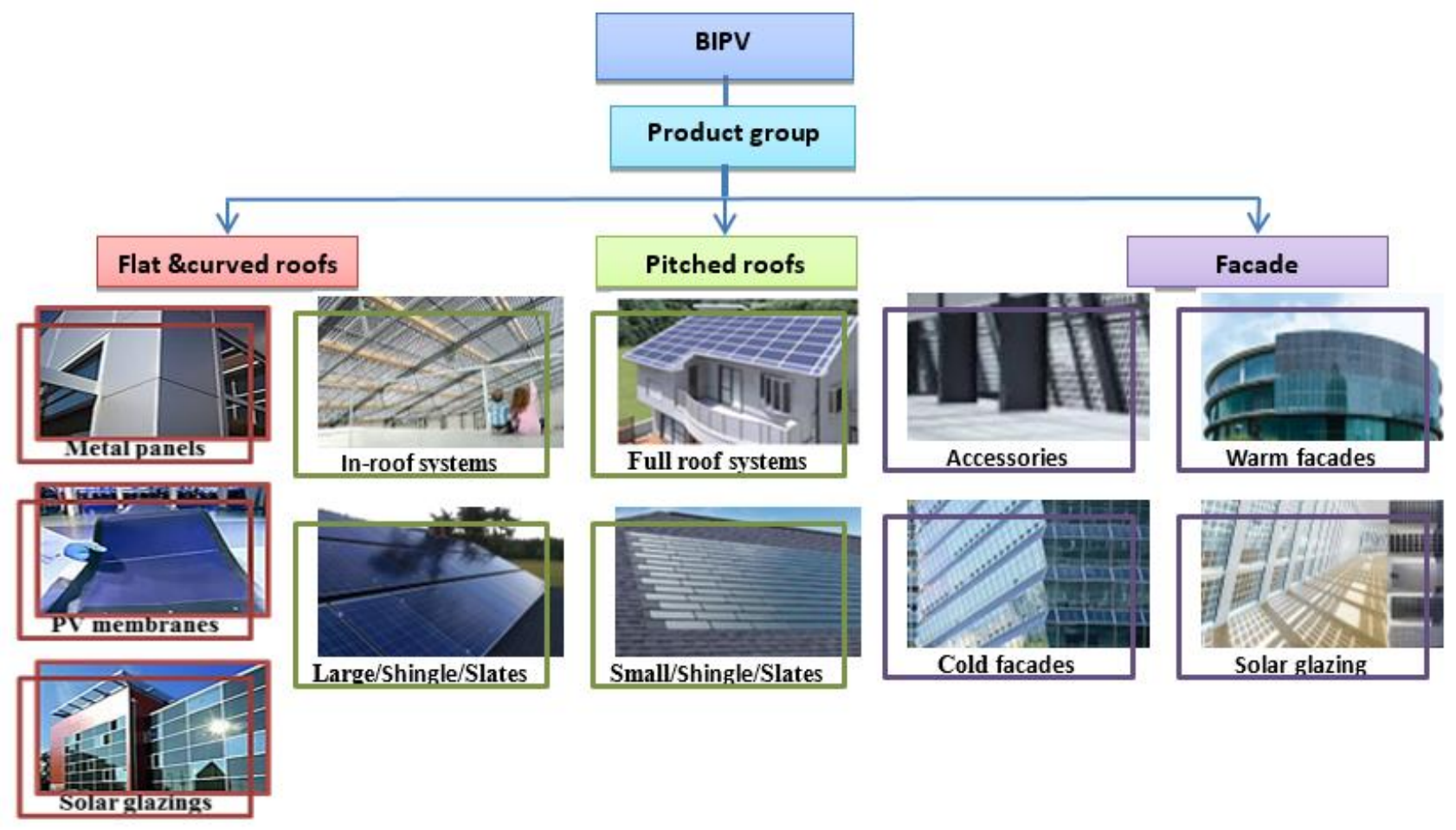

Fig. 1: Product categorization of BIPV, by authors.

Since currently, BIPV is considered New and innovative solutions may minimize costs and reduce the market share, e.g., in the retrofitting market (Shukla, Sudhakar, Baredar, \& Mamat, 2018). "Nevertheless, it currently is predominantly operating in a niche market of 1\% of the global photovoltaics market" (Osseweijer, van den Hurk, Teunissen, \& van Sark, 2018). The market offers a wide range of different model PV models, the work presented in (Delisle \& Kummert, 2016) reviews the current state and prospects of the global and European BIPV market. In addition, a survey of BIPV stakeholders is presented in order to identify key educational gaps, target audiences, and educational objectives (c.f., Fig. 2). In (Xu, Feng, Chi, Liu, \& Dou, 2018), a study on numerous sides is carried out, such as technical progress on specific aspects of design, layout and installation, and operation of systems. (Zhang, Wang, \& Yang, 2018), focused on the technical feasibility of integrating BIPV in a commercial public building using different integration methods in Mediterranean climate. The work presented in (Park, Hengevoss, \& Wittkopf, 2019) summarizes the current state of the BIPV's market and its different modes of installations, including sheet glazing products, tiles, modules, and BIPV solar cells. Also, it presents the advantages and the disadvantages of installing and maintaining BIPVs from both a technological and scientific perspectives, and it studies in details the differences between PV construction added to the building and building-integrated PV.

BIPV systems are considered as an essential functional part of the building construction or an integrated part in the architecture of the building. (c.f., Fig. 3) Shows various architectural integration applications. However, there is a radical problem, which is the standardization of buildings on a global scale, thus neglecting several criteria in the development of PV products, such as aesthetic, religious, cultural, and social 
sides. Consequently, all these issues delay the spread of this technology and acquiescence in the construction market. As a result, the architects are forced to work on the design of what suits these issues, where it is necessary to both prioritize and balance these issues to successfully integrate them into the building. Several studies are focused on the relationship between buildings and architectural quality where PV technology along with its applications has been adopted. The objective of these studies is to present new research topics for the implementation of the use of PV in buildings.

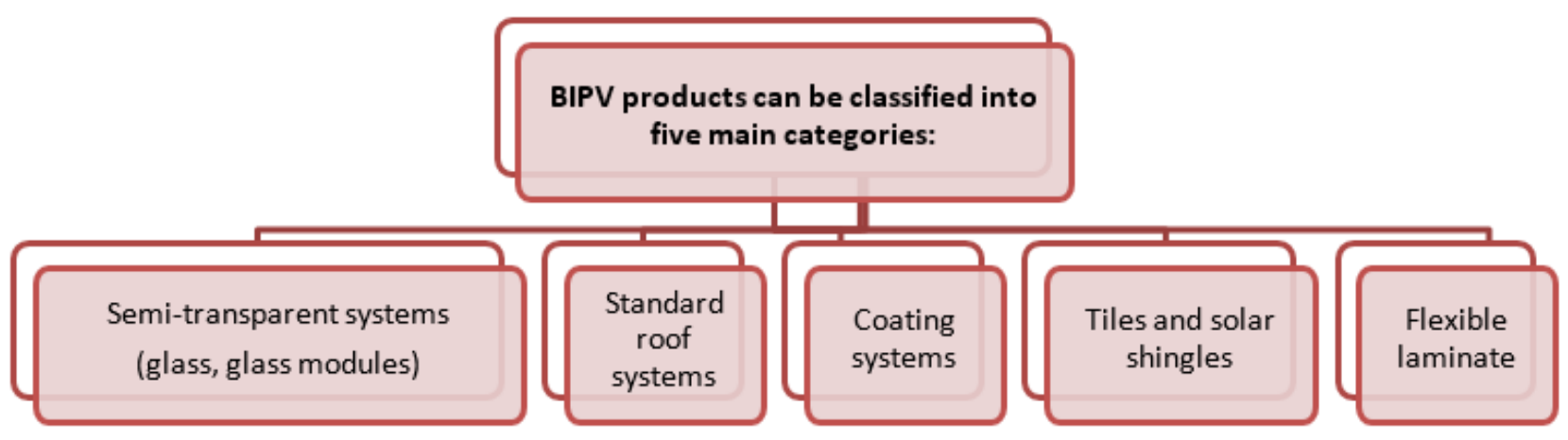

Fig. 2: BIPV products can be classified into five main categories, by authors.

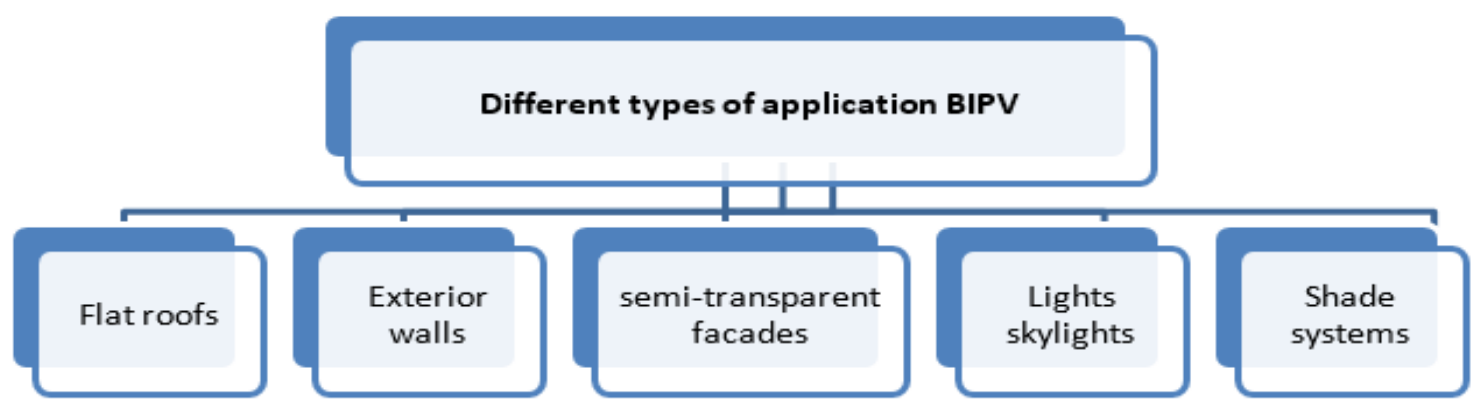

Fig. 3: Different types of application BIPV, by authors.

\subsection{Methodology and Research Question}

This paper reports on the performance of electrical energy in a contemporary building with totally glazed facades, built in a hot desert climate context. This study is also necessary to draw the attention of the highest authorities in Algeria and the world, as well as work to attract the attention of researchers and engineers in order to seek to achieve the use of clean solar energy with innovative and intelligent solutions to manage energy resilience and the transformation of its utilization. The main aspect discussed in this study is the possibility of flexible energy demand in an office building that integrates two different technologies in PV, BIPV in the facade (i) and BIPV in the roof (ii), of a tourist facility located in the city of Bechar. To conduct a comparative study between energy efficiency, economic performance, and Payback Period (PP) for each system. 


\author{
(online) $=$ ISSN $2285-3642$ \\ ISSN-L = $2285-3642$ \\ Journal of Economic Development, Environment and People \\ Volume 9, Issue 1, 2020 \\ URL: http://jedep.spiruharet.ro \\ e-mail: office jedep@spiruharet.ro
}

The main motivations of this work give rise to the following queries:

- Given the difference state art of multi-functional and techniques, marks and models of BIPV, what are the specific requirements of the BIPV electrical installation?

- What are the main advantages and drawbacks of BIPV systems?

- What are the criteria and parameters influencing the energy efficiency of BIPV systems?

- What are the different used BIPV software tools?

- What is the real opinion of citizens on the aesthetic impact resulting from the use of glass technology in buildings? and what is the effectiveness of BIPV on different sides, such as energetic, esthetic, thermic, and economic?

- How to calculate the exact sizing of a given BIPV system according to the energy requirements of the building?

- What is the best installation method of PV in terms of energy efficiency and profitability, and especially on the facade or on the roof?

- What is the duration of budget recovery for each situation? and what are the modalities and techniques of assembly and installation on the facade?

The rest of this paper is organized as follows. Section 2 discusses the different issues of BIPV systems and summarizes all their advantages. Then, Section 3 Presents a review of contemporary architecture in Algeria, and more particularly in a Sahara region. Section 4, diet and climate data of area study (Bechar region), energy consumption (in the city-wide), and the anesthetization at the expense of the thermal comfort. While in section 5, define a location of case study and calculation of a total area of glass in windows, Sizing the BIPV solution.

Section 6, a comparative study between the integration of BIPV system on the roof and the facade. Grid Interaction (i): Energy Consumption, Photovoltaic Generator Sizing Load Matching Analysis(ii): The capacity of energy storage sizing, Energy Generation Economic Assessment(iii): The cost of installation, the economic performance and Payback Period (PP) for each system BIPV of renewable energies incorporated in administrative equipment. Section 7, illustrates the implementation of BIPV integration (based on several cases studies). Finally, the last section concludes this work.

\title{
2. Related work: Literature Review and Current State Challenges and advantages of the BIPV systems
}

The integration of BIPV in the urban environment and buildings offers many benefits: (1) A thermal resistance, (2) Flexibly and more aesthetically materials, and (3) Architecture of BIPV (i.e., renovation and sustainability). In (4) and (5), we present the ecological footprint and economic benefits of BIPV, respectively.

\subsection{The influence of a building's integrated photovoltaic as a thermal resistance}

The incorporation of a system in the facades of the buildings increases the resistance of the walls and prevents the passage of temperature through it, and thus is used as thermal insulation between it and the external environment. This makes it prevent energy loss and maintains a moderate temperature inside space. these studies of (Baljit, Chan, \& Sopian, 2016) analyse the energy and economic performance of roof and/or facades Building Integrated flat plate PV and Thermal (BIPVT) collectors for residential applications. The authors in (Buonomano, Forzano, Kalogirou, \& Palombo, 2019) proposed an appropriate dynamic simulation model for the evaluation of the energy performance, comfort, economy, and environment of the system and they analysed passive and active effects of integration of the solar panels into the building. The study in (Chan, 2018) investigates the effect of PV systems on the thermal performance of buildings. Furthermore, it 
was demonstrated in (Hassanien, Li, \& Yin, 2018) that the BIPV shading decreases the air temperature by $\left(1{ }^{\circ} \mathrm{C}-3{ }^{\circ} \mathrm{C}\right)$ on clear days and has no effect on relative humidity. The BIPV system is promising for the advanced application of the window due to its tremendous ability to minimize heat transfer, control acceptable sun's heat and produce clean, environmentally friendly electricity (Ghosh, Sarmah, Sundaram, \& Mallick, 2019).

\subsection{Flexibly and more aesthetically materials}

BIPV sheets are light, easy and fast to install and install. Add to this transparent and can be attached to the walls and curtains of the facades of buildings. The integration of a system in the facades of the buildings increases the building's attractiveness and distinction. Due to the availability of this system in various colors, materials, and sizes. The work in (Sánchez-Pantoja, Vidal, \& Pastor, 2018) focused on the real opinion of citizens about the aesthetic impact resulting from the use of PV systems in buildings. PV elements can be used with materials that are conjoined in architecture (e.g., glass or metal) in opaque or semi-transparent facades. Also, BIPV systems can be a versatile tool to offer aesthetics, with an innovative and contemporary design that renovates the value of a building (Solangi, Islam, Saidur, Rahim, \& Fayaz, 2011).

Fig. 4: shows the evolution of the BIPV market between 2015 and 2025. Currently, around 50\% of the worldwide BIPV market is associated with non-glass roofing products and it is expected to lead the shipments in the following years. Non-glass walling products will increase its market, reaching and exceeding glass products in a couple of years (Tripathy \& Sadhu, 2015).

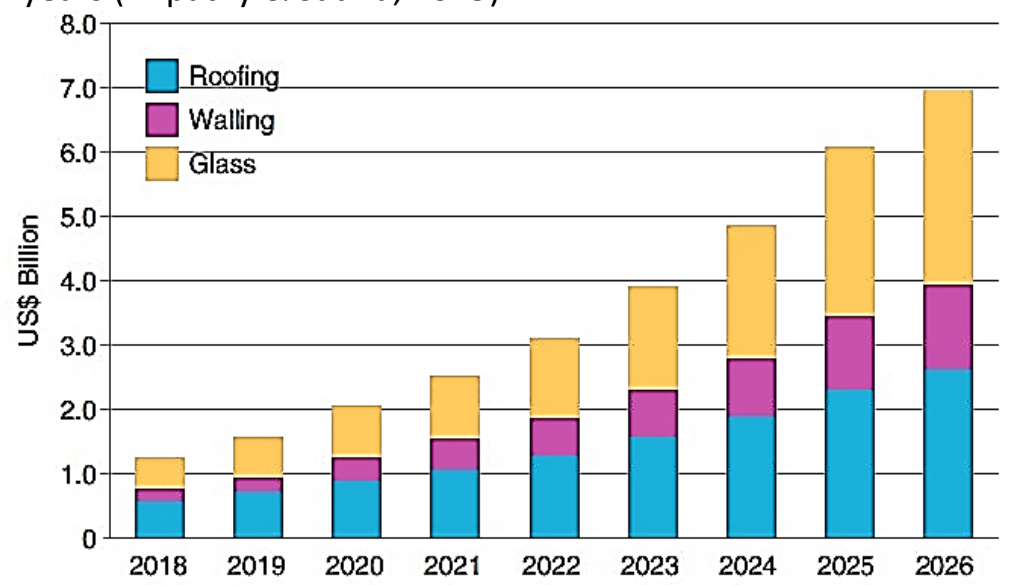

Fig. 4: Global Installed Capacity Projected of BIPV market perspective (2018 -2026) in MW

(Ballif, Perret-Aebi, Lufkin, \& Rey, 2018).

\subsection{Architecture of BIPV: renovation and sustainability}

Generally, the BIPV system allows us to periodically renew building facades, in addition to that it doubles the building's life and this system is also used in new and old buildings. The authors in (Aguacil Moreno, Lufkin, \& Rey, 2017) present an essential process of integrated architectural design for the renovation of projects. It is a comparative study between two cases, the first on archetypal residential buildings from the 1900 s to the 1970s and newly constructed buildings in Neuchâtel, Switzerland. Moreover, the work in (Martin Chivelet, Carlos Gutiérrez, Alonso Abella, Chenlo, \& Cuenca, 2018) evokes the case of building renovation in which standard PV modules are integrated into a new ventilated facade (c.f., Fig. 5.6). The result of the integrated photovoltaic modules in substitution of the polymer concrete panels on the facade is positive, in one hand the panels adhere to the whole of the architectural design of the building on the other hand they have improved the energy efficiency of the building and renewable energy sources. 


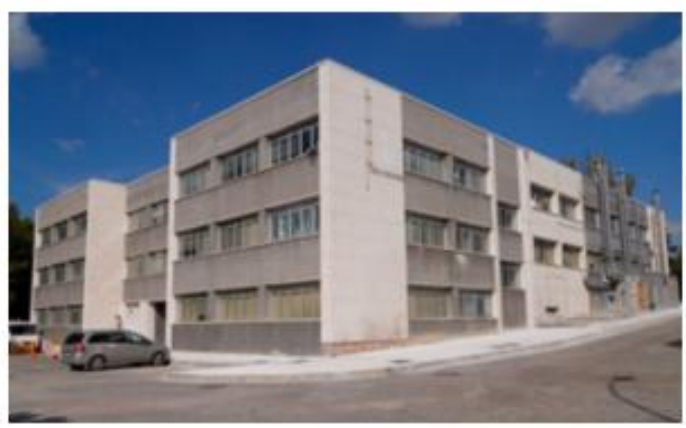

Fig. 5: South-west view of the building Before renovation.

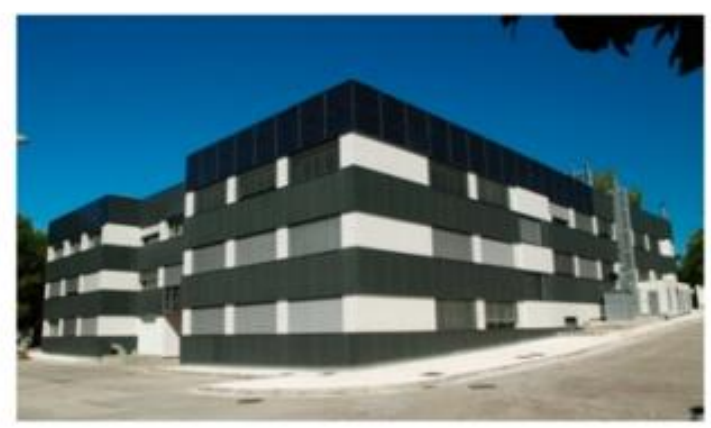

Fig. 6: South-west view of the building After renovation.

\subsection{BIPV and ecological footprint}

Green Energy is the gateway to safety and transit to protect the world from land hazards and pollution. Because of the misuse of harmful and non-renewable energies such as oil, coal, and natural gas (Majid, 2019). The manufacture and consumption of fossil energy resources cause pollutant gas emissions such as carbon dioxide, but with the use of renewable alternative energies such as solar energy and especially the BIPV system, it contributes remarkably and effectively to protecting the environment and preserving the Earth's ecosystem. In ( $\mathrm{Ng} \&$ Mithraratne, 2014), the authors examine the environmental and economic performance of the life cycle of semi-transparent BIPV modules available on the market for window application in Singapore's tropical conditions. PV modules are used as building materials, have a shorter energy payback time (i.e., the time required to produce the energy to compensate for the energy spent on its production), and are recyclable. After examining a global $\mathrm{CO} 2$ balance in the life cycle of a PV energy system, it is confirmed that the real impact of the PV system in terms of $\mathrm{CO} 2$ is in relation to the sum of local grid-related electrical productivity and value for recycling and transmission emission. In (Yang \& Zou, 2016), the authors studied the advantages and obstacles to the use of BIPV technologies, thus the reduction of $\mathrm{CO} 2$ emissions and social costs, the environmental impact of the constructions, the minimal occupation of the grounds, and savings on the invoices of electricity. In addition, on the basis of the literature review of energy recovery time, system lifetime, and greenhouse gas emissions of various BIPV technologies, the progress of research on life cycle analysis of BIPV systems is also reviewed.

\subsection{Economic benefits of BIPV}

Global interest in BIPV has grown following forecasts of a compound annual growth rate of $18.7 \%$ and a total of 5.4 GW installed worldwide from 2013 to 2019 (Attoye, Adekunle, Tabet Aoul, Hassan, \& Attoye, 2018). In (Shirazi, Zomorodian, \& Tahsildoost, 2019), the authors presented an integrated technical-economic assessment tool, which is designed to help architects and engineers, policymakers, and investors, and it identifies the most appropriate PV installation surfaces in urban areas. It was shown that there is a $19 \%$ and $6 \%$ increase in energy generation and an internal rate of return in south walls. The economic analysis of the study (Gholami, Røstvik, \& Müller-Eie, 2019) showed that with the social and environmental benefits of the applied system, replacing traditional facades and roof building materials with BIPV units will be more economical and feasible. As a result, directing governments or decision-makers to support this modern technology by spreading awareness and encouraging investment in them.

The BIPV windows showed great potential for energy savings, e.g., about $12 \%$ to $21 \%$ in annual energy use, and $14 \%$ to $26 \%$ in peak cooling demand (Do, Shin, Baltazar, \& Kim, 2017). The annual analysis in (Brito, Freitas, Guimarães, Catita, \& Redweik, 2017) shows that roof and facade PV potential exceeds the local non- 
baseload demand and can contribute to $50 \%$ to $75 \%$ of the total electricity demand. In addition, conservative economic analysis shows payback times below 10 years can only be achieved with PV on roofs while a 50/50 mix would lead to payback times of 15 years. To estimates investments in BIPV energy translate into: an assessment of the financial benefits against the estimated direct economic costs of the system being evaluated. As following: Cash flow

Projected Benefits $=$ Value of electricity produced.

Estimated costs $=$ capital costs + periodic costs + replacement costs.

\section{Contemporary architecture in Algeria}

Algeria is the largest country in Africa located in the North of Africa on the Mediterranean coast. It is separated topographically into three main regions: (i) the Mediterranean coastal area, (ii) high Plateaus with semiarid climate, and (iii) the Sahara, which covers almost $80 \%$ of Algeria's territory. According to the German Space Agency (GSA), they have recorded, through satellite assessments, the highest solar irradiation rate, which reflects unusual levels of sunshine in the order of $1200 \mathrm{kWh} / \mathrm{m}^{2} /$ year, in the North of the Great Sahara. On the other hand, in southern Europe, the preferential solar irradiation rates are $800 \mathrm{kWh} / \mathrm{m}^{2} /$ year. The German Space Agency (GSA) has defined, that the solar potential of Algeria ranked the best with a greater quantity compared to the entire Mediterranean basin, according to (Lamy, 2004), that is $169.000 \mathrm{TWh} / \mathrm{year}$ for solar thermal, 13.9 TWh/year for solar PV. As defined in (" Ministère de l'Énergie-Algérie-Potentiels des Energies recoverables ", s. d.), the energy received daily on a horizontal surface of $1 \mathrm{~m}^{2}$ is of the order of $5 \mathrm{kWh}$ over most of the national territory, or nearly $1700 \mathrm{kWh} / \mathrm{m}^{2} /$ year in the coastal region, for the average energy received at the high trays $1900 \mathrm{kWh} / \mathrm{m}^{2} /$ year and $2250 \mathrm{kWh} / \mathrm{m}^{2} /$ year in the south of the country. Thus make, solar energy development is convenient due to the climatic conditions in Algeria throughout the year.

In Algeria, the residential sector is a non-productive, but energy-intensive sector, which consumes $41 \%$ of final energy ahead of the agricultural sector, which absorbs $33 \%$ of energy, as well as the industrial and transport sectors, with respective rates of $19 \%$ and $7 \%$. Overall, the energy consumption in Algeria has increased by $43 \%$ and the residential electricity consumption increased by $50 \%$ over the period between 2010 and 2014. Cooling, heating, and lighting are the major means of energy consumption in the residential sector in Algeria and that is because of the total end-use in Algeria (c.f., Fig.7).
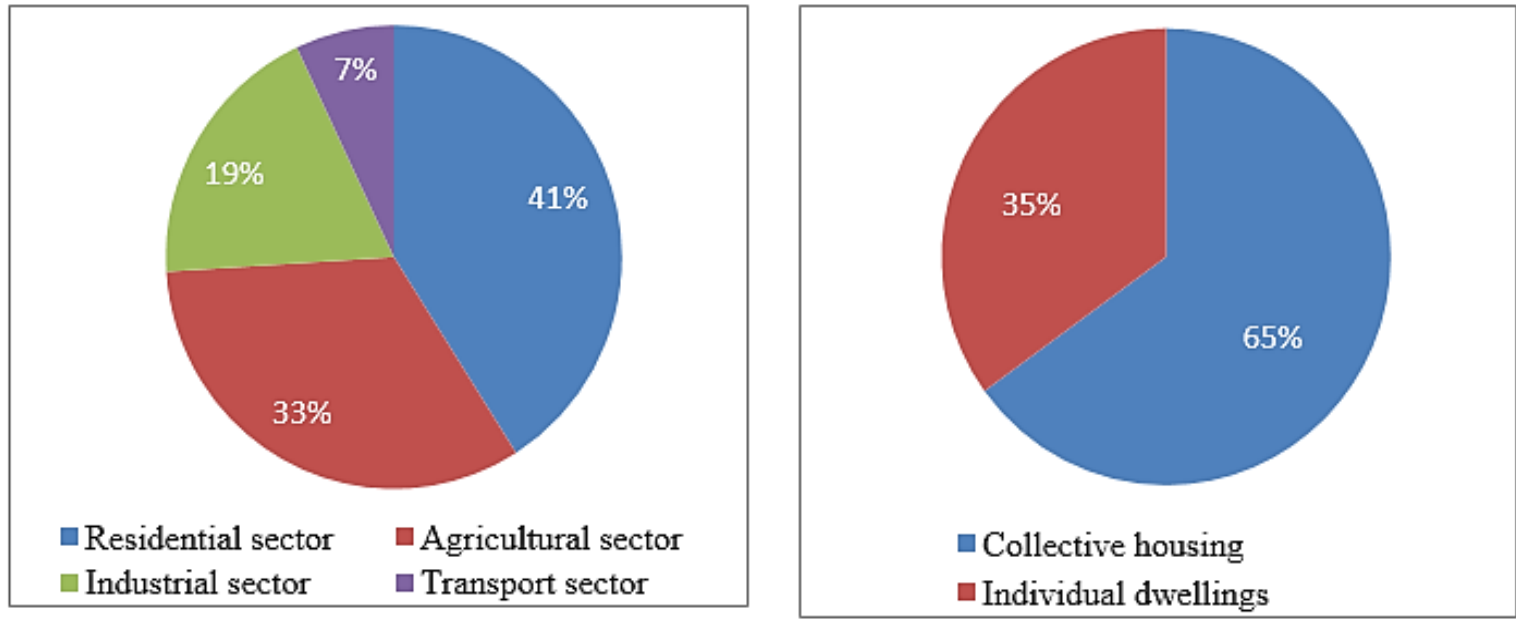

Fig. 7: Energy consumption by major sectors in Algeria, by authors. 
So, the exploitation of this renewable energy the solar PV via the integrating in the building as a BIPV system is insufficient and almost no-existent. As elsewhere, there has long been the use of glass in Algeria. It is one of the most popular building materials, confined to small windows to let the light, as well as areas of modest sizing, given its limited manufacturing processes. However, the development of architecture promotes and diversifies its use, where the glass is actually prominent in the design and opens multiple perspectives as to the conjugation of its use, which becomes virtually unlimited. Bold innovations of architects project the idea of transparency into ambitious projects, such as office, administrations, and hotels (c.f., fig. 8). It is to give a sense of light in the most spectacular way in space. In this era of modernity, can we shy away from the design of facades entirely in glass, for the simple reason that the environment specifies by extreme climate?

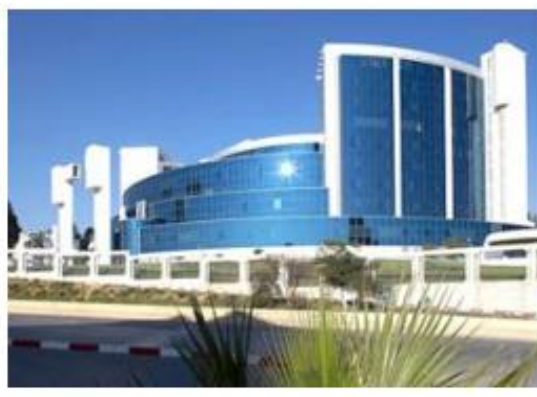

(a) Ministry of Finance, Algiers.

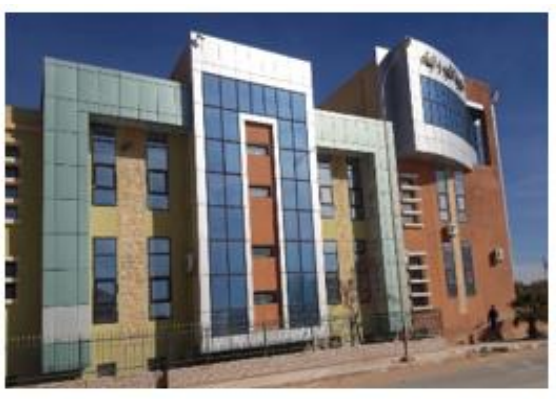

(b) Department of Directorate of Population. and Urbanization, Bechar.

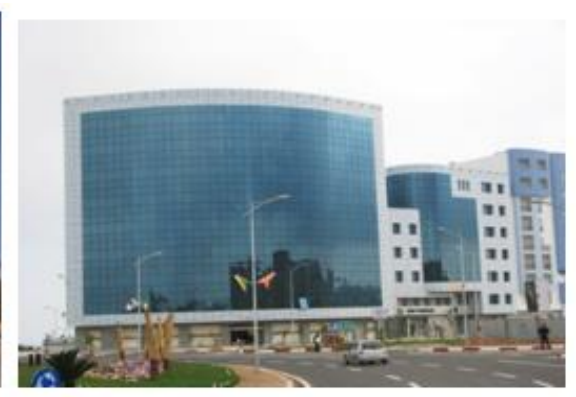

(c) Plaza, Oran.

Fig. 8: Facade cladding of building and the architecture in glass in Algeria, by authors.

\subsection{BIPV as an alternative}

A BIPV system has its own advantages. Firstly, it is a kind of no-polluting green energy, it has no side effects on the ecosystem, and it is also a recyclable energy source. Secondly, it is very profitable for the city whose land is very expensive, and it can save installation space because it does not take up too much space. Third, it is designed to save energy in buildings using intelligent PV panels that absorb energy from the sun and convert it into electricity, which significantly reduces the indoor temperature of buildings and the pressure of the air conditioner. Moreover, it has the ability to save energy and reduce $\mathrm{CO} 2$ emissions and protect ecosystems.

BIPV is one of the best ways to exploit and invest in solar energy. This system will be in addition to the benefit that brings the innovation of architectural design and the building becomes more aesthetic and their installation is easy. Designed for different types of buildings, BIPV systems fit perfectly with the architecture and flexible both in terms of ease of Assembly and geometry and they can an active feature of green energy generator (energy supply). Consequently, BIPV systems become the most powerful and favorable technology requiring no additional installation place. The advantage of the BIPV compared with normal PV panels is that they fit in the buildings and attracting the interest of people. The BIPV module becomes a fundamental part of the functionality of the building (i.e., it is used as an architectural component). The shaded face of a BIPV system can also be used as shade from the Sun as a constructive and architectural ornament, and sun protection device (sunscreen). These systems should be a functional part of the structure of a building or should be structurally integrated into its design (Peng, Huang, \& Wu, 2011). In addition, it is regarded as a source of natural light, and thereby reducing the absorption of heat by the Sun (i.e. external insulation and waterproof). Also, it is important to consider the effect of such panels of system noise reduction in double skin facades or vertical flat surfaces makes a positive contribution in this aspect. 


\author{
(online) $=$ ISSN $2285-3642$ \\ ISSN-L = 2285-3642 \\ Journal of Economic Development, Environment and People \\ Volume 9, Issue 1, 2020 \\ URL: http://jedep.spiruharet.ro \\ e-mail: office jedep@spiruharet.ro
}

\title{
3.2. Comparative study between ordinary glass and BIPV in buildings
}

The urban landscape of the city of Algiers, Algeria, has appreciated a spread of reflective glass façades of new and rehabilitated office buildings. This type of glass can generate visual glare in outdoor spaces and may lead to indoor thermal discomfort. Today, the glass curtain walls have been recently introduced in Bechar. They are seen as a new fashion and are highly valued by some of their pleasing aesthetics. Saharan architecture in Bechar is experiencing radical change and more remarkable development. For instance, the transparent and impermeable facades are noted by the lack of identity of these constructions in this territory. In addition, the complete break with the context of the urban environment, as well as socio-cultural and climatic conditions, traditionally, man has adapted his activity and his building techniques to the climate. The traditional Saharan buildings are characterized by very high thermal capacity with ochre color, blind facades with small exterior openings for social-cultural reasons (of intimacy) and for environmental reasons (natural cooling), shadowing devices, and narrow streets. Nowadays, all these behaviors and traditions are becoming less and less frequent because of the modern style of life. The appearance of new building materials like modern bricks, concrete, steel, and glazed buildings, are replacing the traditional Medina with highly massive buildings.

The glass has become a very essential building material in modern architecture. It offers opportunities for lightened, open, and bright buildings. The great concept is to move away from the massive and blind walls in favor of an opening transparent and translucent on the outside. However, unfortunately, the adopted ordinary glazing is non-resistant in the envelope of tertiary buildings of the city of Bechar. The ordinary glass has been invaded by the market of construction, which caused problems with thermal and durability. Since the glass has good thermal conductivity and significantly influences the energy performance of the facades, the impact of glazing on energy consumption and comfort. Also, it reflects negatively on the performance of people. For architectonic reasons, the outer layer is usually complete entirely of glass, while the indoor layer may be partially opaque. This technique permits direct solar gains to be decreased and increases the thermal inertia of the building.

In areas with a hot climate like in Bechar, a reduction in the radiative heat transfer reduces the cooling demand and hence energy usage. In cold climatic regions, keeping the heat from radiating to the outside helps to decline heating wishes in the winter. The $U$ Value is reliant on upon climatic conditions, which means that the transmittance of heat through a glazing system change. The U-value and SHGC of the windows are important parameters that influence the cooling energy demands of a building. Single glazing systems are presently most usually used, and the normal U-value of the windows in the database buildings was 5.8 $\mathrm{W} /\left(\mathrm{m}^{2} \mathrm{~K}\right)$, which corresponds to a laminated glass of $08 \mathrm{~mm}$ thickness. A U-factor is $2.8 \mathrm{~W} /\left(\mathrm{m}^{2} \mathrm{~K}\right)$ for a doubleglazing and $1.1 \mathrm{~W} /\left(\mathrm{m}^{2} \mathrm{~K}\right)$ for module PV. A U-factor of $0.6 \mathrm{~W} / \mathrm{m}^{2} \mathrm{~K}$ is one of the best possible currently and increases from there. For example, Triple glazing typically produces $\mathrm{U}$-factors between 0.4 and $0.8 \mathrm{~W} /\left(\mathrm{m}^{2} \mathrm{~K}\right)$ (See table 02). The U-value of a single sheet of glass as found in a traditional windowpane is $5.8 \mathrm{~W} /\left(\mathrm{m}^{2} \mathrm{~K}\right)$. This means that for every degree of the temperature difference between the outside and the inside, a square meter of the glazing would lose 5.8 watts. So, for example, if the temperature difference on a hot day was 20 degrees, then the amount of heat loss would be $16 \times 5.8=116$ watts per square meter. By comparison, the $\mathrm{U}$-value of a modern piece of triple-glazing can be as low as $\mathrm{W} /\left(\mathrm{m}^{2} \mathrm{~K}\right)$, which is not very much heat at all. The improvement of the windows $U$-value increases the annual cooling energy demand. With very low U-values, the temperature increment could be slightly reduced in interior space, but during the night, lower U-value impedes the evacuation of the stored heat.

In the summer, Bechar has a warm climate and the using of air conditioning is inevitably to provide a convenient working atmosphere and comfortable indoors. But this is an unpopular solution because it consumes considerable energy. To solve this problem must be ensured a low coefficient of ( $\mathrm{g}$ ) which means less heat by solar radiation. One of the solutions you can suggest is to try to solve this problem must be 
ensured a low coefficient of $(\mathrm{g})$ which means less heat by solar radiation. $(\mathrm{g})$ is also called TSET (Total Solar Energy Transmittance). It expresses the ratio between total solar radiation on an element and the part of this energy that is transmitted through the element in the building. So, it determines the total fraction of direct solar energy transmitted inside the room. This value expresses the thermal energy that penetrates into the premises through solar radiation. This value is made up of two factors, the radiant energy from the sun that enters the premises by direct transmission through the glazing and the energy that this cedes, as thermal energy inside the premises after having been absorbed by the glazing and having produced its reheating. The lesser the $g$ value is, the better the protection against reheating is. For the traditional glass, the coefficient $(\mathrm{g})$ is $86 \%$. This caused a large solar ray penetrating into the interior spaces of the building through the glass spaces, especially in the contemporary glass-covered building. But with the use of new technologies, we can improve the internal temperature of the structural building. We can replace the traditional glass with the BIPV technology, as this type of intelligent glass reduces the penetration of radiation and coefficient $(\mathrm{g})$ is between (15-18\%). This technique enables the architect to improve the temperature conditions inside a space. Thus, we become more controlled in our use and consumption of electrical energy in the building. While preserving the outer contemporizing envelope of the building.

Glass is the ideal material to make the connection between inside and outside, the BIPV (Light Transmission ( $\mathrm{TL}$ ) is less than $50 \%$ ) allows to optimize the penetration of natural light in the building and gain in autonomy. It also allows the provision of natural lighting inside the building without resorting to artificial lighting. Where the nature of the lighting is controlled and the degree of illumination is not focused, which enables us to avoid a glare problem, and allows the occupants to control glare that is embarrassed to perceive objects. Which may be caused by traditional glass (Light Transmission (TL) is $90 \%$ ) to enter the sunlight concentrated in the interior without reflection to the outside (See Table.01).

Table 01. Comparisons of aspects and thermal behaviors between different configurations of glasses systems and a module double PV glazing of BIPV, SOURCE: https://www.energieplus-lesite.beet Schott Solar AG \& ISAAC-SUPSI.

\begin{tabular}{|c|c|c|c|c|}
\hline \multicolumn{2}{|r|}{ Type of glazing } & Coefficient $U\left(\mathrm{~W} / \mathrm{m}^{2} . \mathrm{K}\right)$ & Light Transmission TL \% & Solar Factor FS \% (g) \\
\hline Simple & Clear $(8 \mathrm{~mm})$ & \begin{tabular}{|c|}
5,8 \\
\end{tabular} & 90 & 86 \\
\hline \multirow{7}{*}{ Double } & Clear & 2.8 & 81 & 76 \\
\hline & Clear + low emissivity & 1,6 & 70 & 55 \\
\hline & Clair + absorbent & 2,8 & 36 à 65 & 46 à 67 \\
\hline & Clear + reflective & 2,8 & 7 à 66 & 10 à 66 \\
\hline & Clear + low emissivity $\&$ reflective & 1,6 & 71 & 40 \\
\hline & Clear + low emissivity + insulating gas & 1 à 1,3 & 70 & 55 \\
\hline & $\begin{array}{c}\text { Clear }+ \text { low emissivity+ reflective + } \\
\text { insulating gas }\end{array}$ & 1 à 1,3 & 71 & 40 \\
\hline \multirow{3}{*}{ Triple } & Clear & 1,9 & 74 & 68 \\
\hline & Clear + low emissivity + insulating gas & $0,6-0,8$ & $65-75$ & $50-70$ \\
\hline & $\begin{array}{c}\text { Clear }+ \text { low emissivity (in) }+(\mathrm{ex}) \text { solar } \\
\text { control insulating gas }\end{array}$ & $0,4-0,6$ & $60-70$ & $30-40$ \\
\hline \multicolumn{2}{|c|}{ PV module - SC-Si with glazing insulating } & 1.1 & \multirow{4}{*}{ Many models } & 15 \\
\hline \multicolumn{2}{|c|}{ PV module - a-Si/a-Si with glazing insulating } & 1.1 & & 12 \\
\hline \multicolumn{2}{|c|}{ PV module - a-Si-Si with glazing insulating } & 1.2 & & 18 \\
\hline \multicolumn{2}{|c|}{$\begin{array}{l}\text { PV module micro-morph module with glazing } \\
\text { insulating. }\end{array}$} & 1.2 & & 15 \\
\hline
\end{tabular}




\section{Environment of Bechar region and people: subject to all land challenges}

Since the dawn of time, despite the infinite expanse, despite supreme aridity, the Earth in the Sahara is filled with life. The men struggling for survival, became Lords in the transformation of the Saharan oasis reliefs; giving them excepts both on the architectural level and hydraulics. So, despite the asceticism of the climate and these changes, the settlement was not ousted in the Sahara. The severe climate change adaptation actually sets this land, including Bechar city part ownership. If in this city located at the doors of the Sahara, the traditional architecture adapts to social context and climate, or even environment, which cannot outline the current city. Since solar radiation caused excessive heat, our role as architects is to propose architectural and technical solutions, such as the integration of shading elements to evacuate solar radiation.

\subsection{Diet and climate data of area study (Bechar region)}

Every designer needs to know about the climate of the place where we have to build. That is to say: "The system of temperature and moisture in the air, the regime and the nature of precipitation, sunshine, plan, and the nature of the winds during the annual cycle". The town of Bechar shows indeed a semi-arid climate of harsh regime and heating in winter is not a big problem because of the availability of cheap fossil fuel. Therefore, the buildings must be designed according to the demands of summer and this because the climate in this region is very hot, since sometimes even refrigerants may be insufficient to cool internal spaces to ensure comfortable indoor climates. As for the winter in this region is not long and may not exceed three months.

In summer, Bechar enjoys a completely different thermal system climate and the temperature may exceed $45^{\circ} \mathrm{C}$ in the shade (c.f., Fig.9a), and the relative humidity remains low (4\% to 20\%) with rare and irregular rainfall during tongues where it remains low between $11 \mathrm{~mm}$ to $16 \mathrm{~mm}$ (c.f., Fig.9e). on the other side. In winter the temperature can drop to below zero degrees Celsius sometimes. In addition to all the difficult climatic conditions that characterized this region during the seasons, there are strong hot winds and often accompanied by dizziness of sand and dust (sandy winds), its speed can reach $100 \mathrm{~km} / \mathrm{h}$. The climatic analysis of the city of Bechar confirms the harshness of living throughout the year. Even inside buildings are uncomfortable and the state has a long summer day, hot and relatively balanced and sometimes mild winters, but the positive thing is that it is full of strong sunlight which can exceed 3500 hours per year. The global radiation in this region is exceeded $9 \mathrm{kWh} / \mathrm{m}^{2}$ (c.f., Fig.9b), The direct solar radiation that can be up to 250 $\mathrm{kW} / \mathrm{m}^{2}$ on a horizontal plane (c.f., Fig.9c). And duration of sunshine is limited to 10/14 hours per day throughout the year.

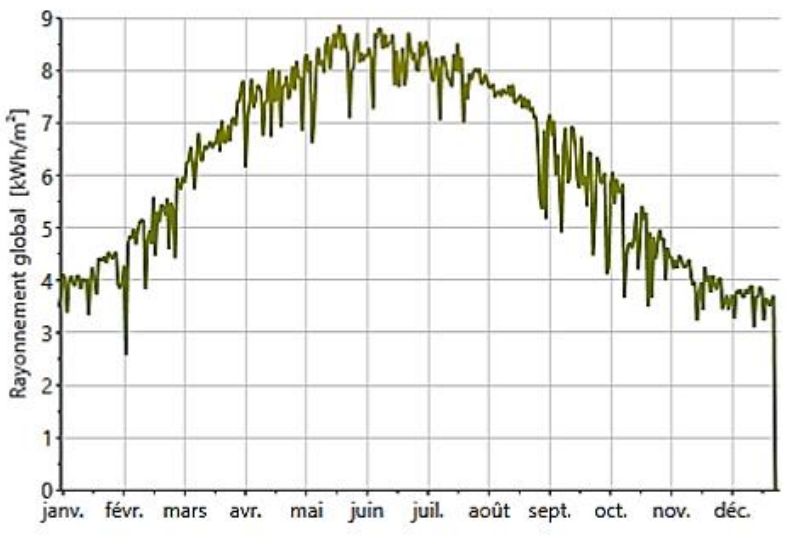

(a) Temperature.

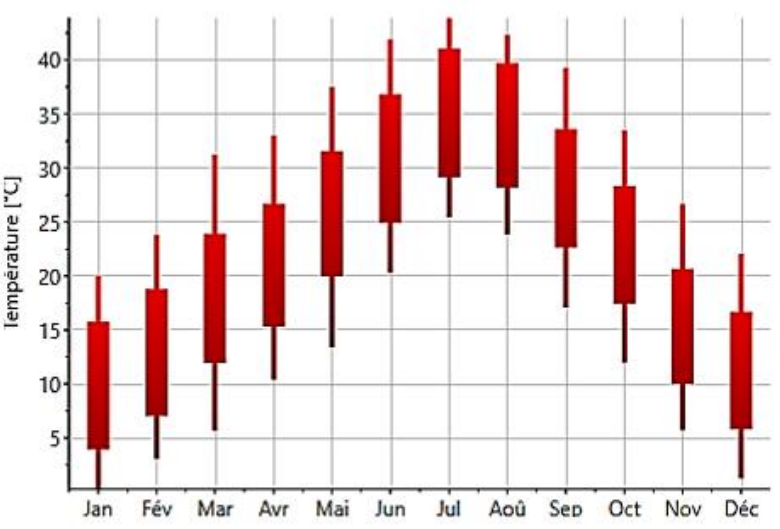

(b) Global Radiation. 


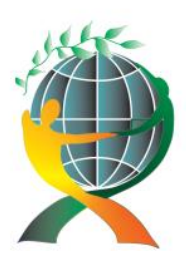

(online) $=$ ISSN $2285-3642$

ISSN-L = 2285 - 3642

Journal of Economic Development, Environment and People

Volume 9, Issue 1, 2020

URL: http://jedep.spiruharet.ro

e-mail: office jedep@spiruharet.ro

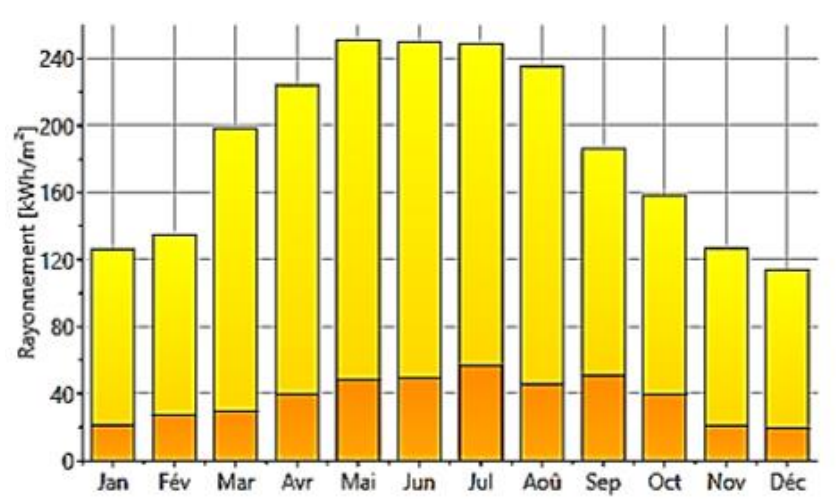

$\square$ Rayonnement diffus $\left[\mathrm{kWh} / \mathrm{m}^{2}\right] \bigcirc$ Rayonnement global $\left[\mathrm{kWh} / \mathrm{m}^{2}\right]$

(c) Radiation.

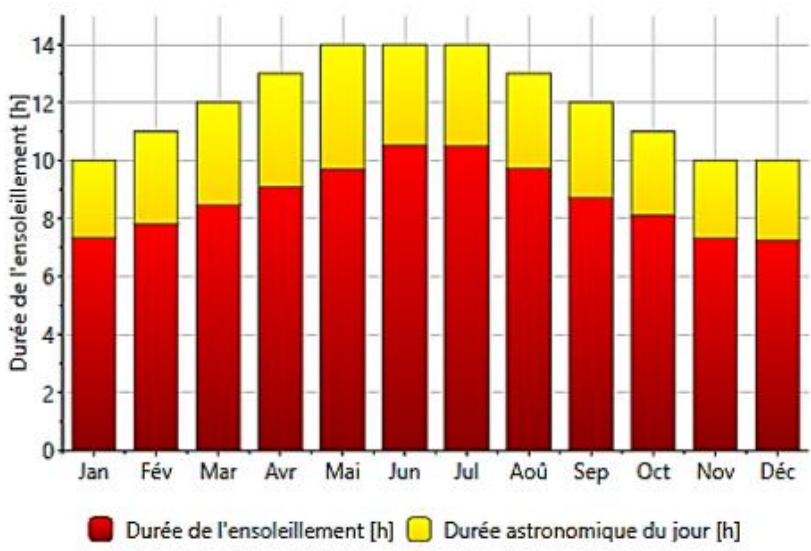

(d) Duration of sunshine.

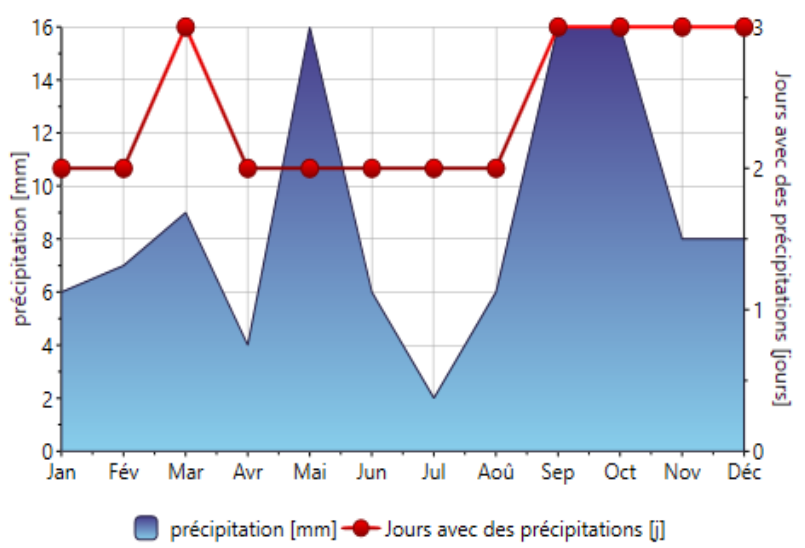

(e) Precipitation.

Fig. 9: Monthly weather data of Bechar, by Metronome.

\subsection{Energy consumption (in the city-wide)}

Severe weather in the town of Becher earmarked a large part of energy consumption for the purposes of heating and cooling as to ensure thermal comfort. This is complemented by the fact that warm periods extend over the longest period of the year, then, buildings of houses and the vested sectors to trade are among the sectors most consumers into electric energy, they exceed the (105 GWh). 'MT' industrial building sector consumes about him (42.5 GWh), then we have (17 GWh) for the electrical consumption of the tertiary facilities. The figures below present energy consumption (electricity and gas) in the town of Becher between 2006 and 2008, (c.f., Fig.10). It's observed an increase in annual energy consumption, which shows that there is an ever-growing energy need (c.f., Fig.11). 


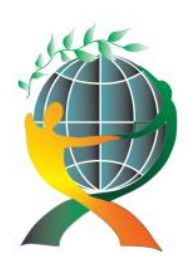

(online) $=$ ISSN $2285-3642$

ISSN-L = $2285-3642$

Journal of Economic Development, Environment and People

Volume 9, Issue 1, 2020

URL: http://jedep.spiruharet.ro

e-mail: office jedep@spiruharet.ro
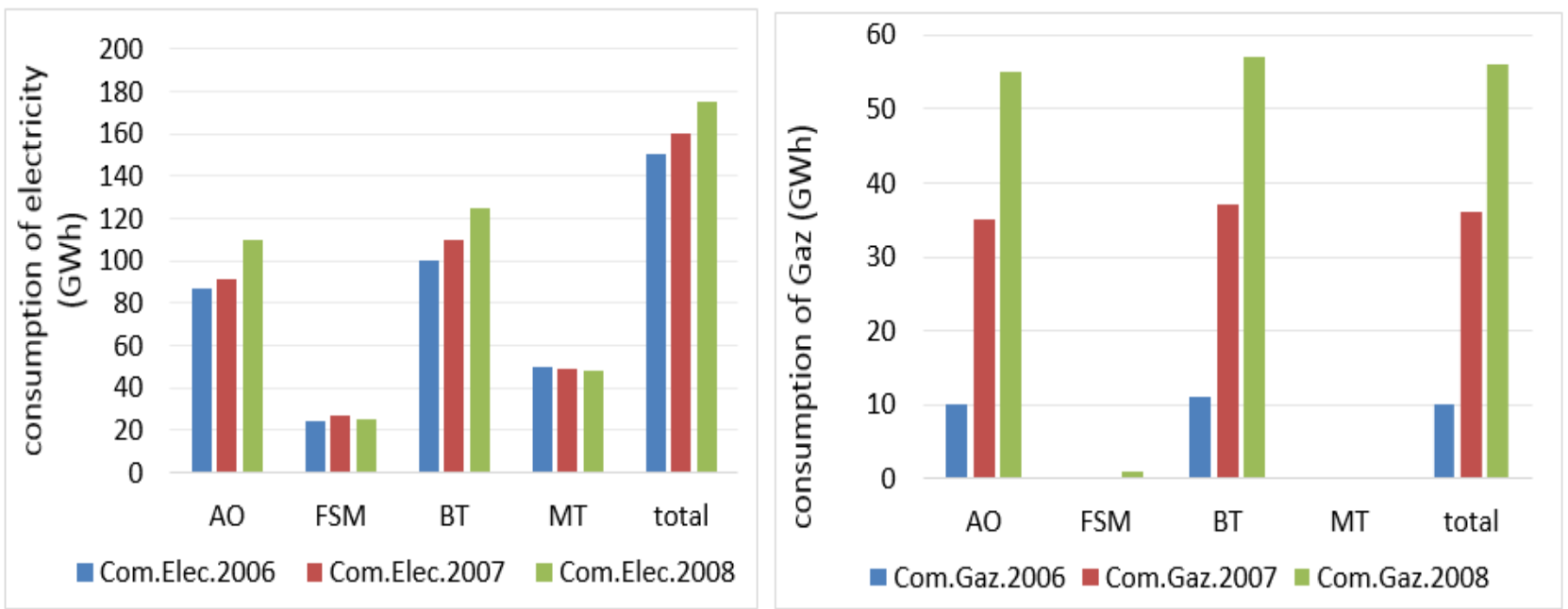

AO: Residential building, WSF: administrative building, BT: Low voltage (AO + WSF), MT: medium voltage residential building.

Fig. 10: Annual electrical energy consumption of a town of Bechar in GWh.
Fig. 11: Annual energy consumption of gas in the town of Bechar in GWh.

\subsection{The anesthetization at the expense of the thermal comfort}

Notwithstanding Supreme weather data and the harsh temperature that characterizes the city of Bachar and despite the intensive efforts of the engineers to achieve buildings suitable to the nature of the climate prevailing in the region. The city is increasingly invaded by constructions in curtain wall, aluminum, a glass of engineering architecture that offers an attractive aesthetic of the outside. This kind of buildings is still criticized by citizens and users. For some, the adoption of the architecture of the glass symbolizes elegance and modernity to the image of the West. For others, the excessive use of this material creates very reversible energy effects, (see the opinions of the masses in figure 12. In winter, it causes significant heat losses and, in the summer, solar radiation warms up excessively spaces due to the effect of the greenhouse of glass. However, a transparent or translucent façade insulates always much less than an opaque wall. The effect of glass panels in the greenhouse. However, a transparent or translucent façade insulates always much less than an opaque wall.
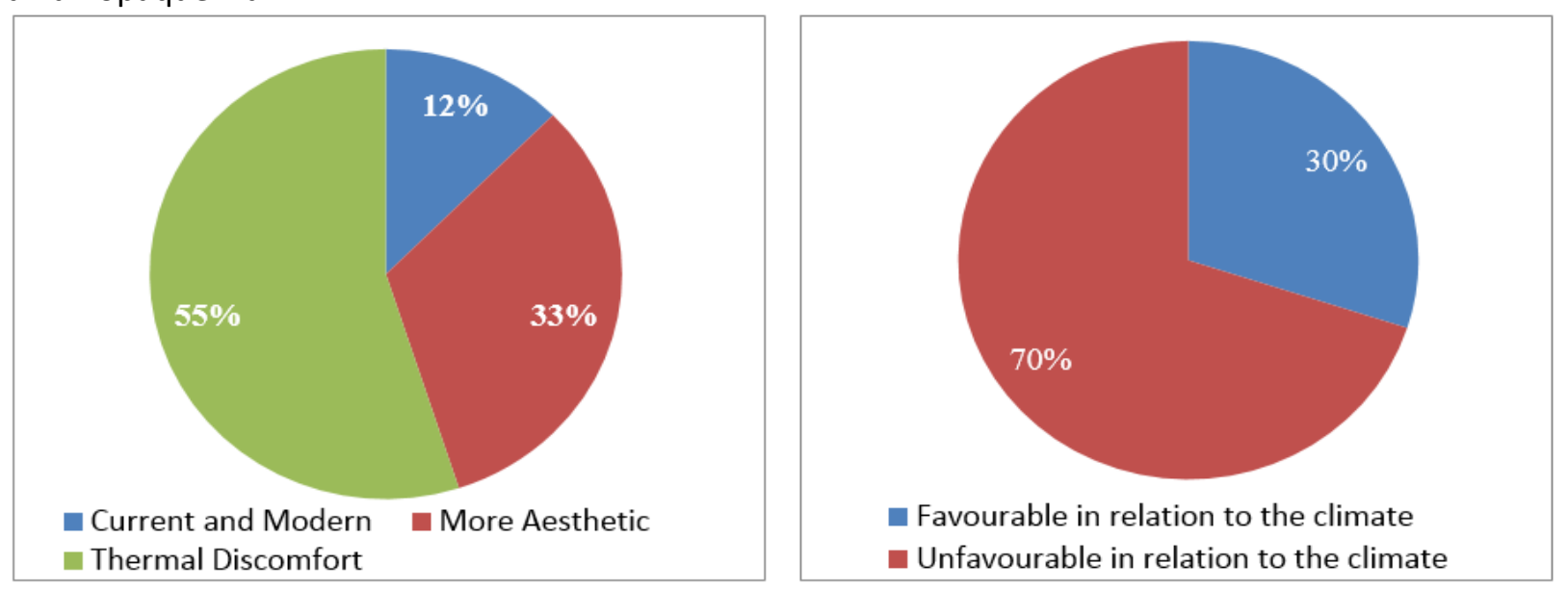

Fig. 12: Opinions of residents on the presence in the force of the glass on the facade panels, by authors. 


\section{Study context: Introduction of the BIPV in a government building}

BIPV systems considered among the most suitable technical solutions. That enables us to design the facades of contemporary architecture covered with glass, attractive, elegant, contemporary and more economical. At the same time, these facades can produce electricity from a solar renewable energy source. But the main objective of this study is to conduct a comparative study, between two different instances of installation BIPV in the same building. First case study (i) The integration of BIPV on the facade of the building, and the second case study (ii) installation of BIPV above of roof. Which is more efficient in terms of energy production and economic benefit? And what is the time period necessary for the retrieval of the amount spent on the purchase of the BIPV system and the amount spent on installation and maintenance in both case studies (i) and (ii)?

\subsection{Location}

The case study is conducted on a governmental building (an office building) existing in Bechar, it is located in the Sahara region. This equipment has a located define as Latitude $31.63^{\circ} \mathrm{N}$, Longitude $-2.22^{\circ} \mathrm{E}$, Altitude 789, (c.f., Fig. 13). And see also Table 2. This building is located along the main road leading to the airport. Adjacent to many administrative buildings of contemporary architecture. It is an administrative center for tourism.

Table 2. Table of geographical coordinates.

\begin{tabular}{|c|c|c|}
\hline $\mathbf{P}$ & Soil Reflectivity or Albedo & 0.12 \\
\hline Lat $_{\text {Lon }}$ & Latitude & $31.63^{\circ} \mathrm{N}$ \\
\hline LLT & Longitude & $-2.22^{\circ} \mathrm{E}$ \\
\hline $\mathbf{T}_{\max }$ & Altitude & $789 \mathrm{~m}$ \\
\hline $\mathbf{T}_{\min }$ & Maximum temperature & $-10^{\circ} \mathrm{C}$ \\
\hline $\mathbf{T}_{\mathbf{c}}$ & Memperature at $1000 \mathrm{~W} / \mathrm{m}^{2}$ & $60^{\circ} \mathrm{C}$ \\
\hline
\end{tabular}

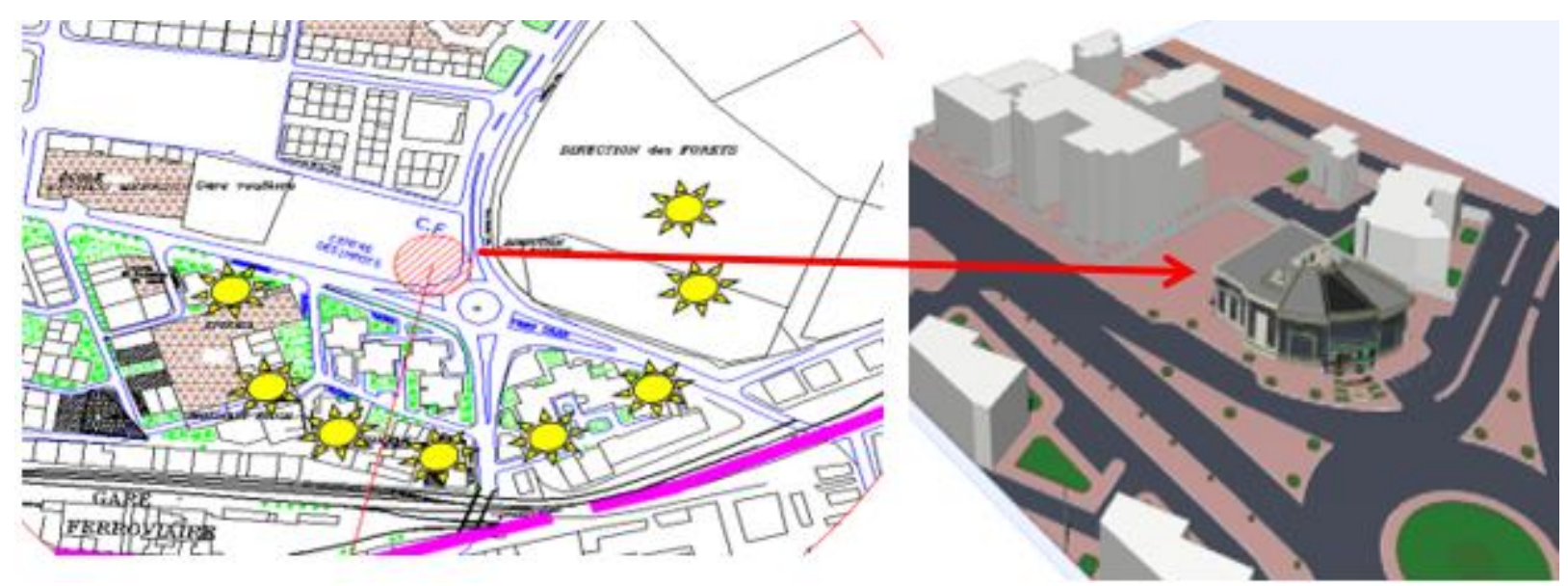

Fig. 13: Location and mass map and external views of case study in Bechar, by authors.

\subsection{Calculation of a Total area of glass in windows}

The main facade of our study project is oriented towards the (South - West). The first stage we conducted in our study is: Calculating the total area of the facade of the building, which was estimated at $1269 \mathrm{~m}^{2}$. Then, we calculated only the transparent areas covered with glass in the same facade. where we found an 
URL: http://jedep.spiruharet.ro e-mail: office jedep@spiruharet.ro

estimated about $412.16 \mathrm{~m}^{2}$. This means, that the percentage of this transparent area is estimated at $32.4 \%$ of the total area of the building facade (c.f., Fig. 14). The reason for calculating this area (glass-covered windows). To make sure that this space is enough to replace ordinary glass with smart glass energy-producing in the facades. Also, to make us sure that this space of integration of BIPV is sufficient to cover the energy needs of the building. Which, is this enough area to integrate the PV panels? Is this area sufficient to produce electricity that covers the energy requirement of equipment?

To confirm whether this space is sufficient or not! Firstly, we determined the electrical needs of the equipment. Secondly, we have calculated the necessary area of BIPV to cover the needs of energy in the building (To cooling and lighting, and management of office tools). So, the sizing of a BIPV is based on the evaluation of the electrical energy needs (Average Daily Consumption ADC) users. We simulated our study with the virtual tool PVsyst. The simulation was primarily made in order to comprehend the behavior of gridtied PV installations at a specific location.

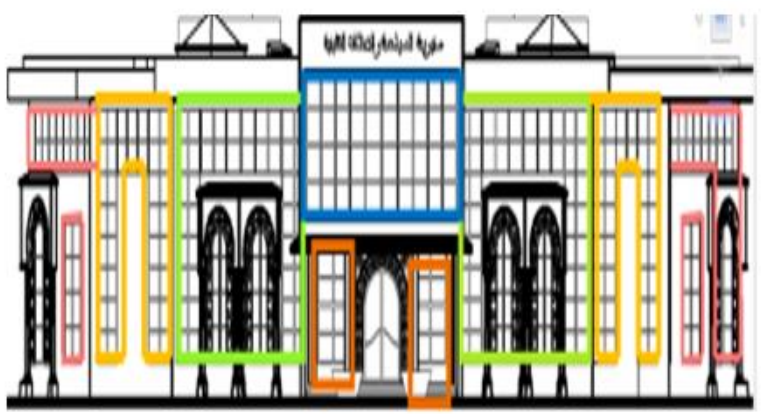

(a) Main façade.

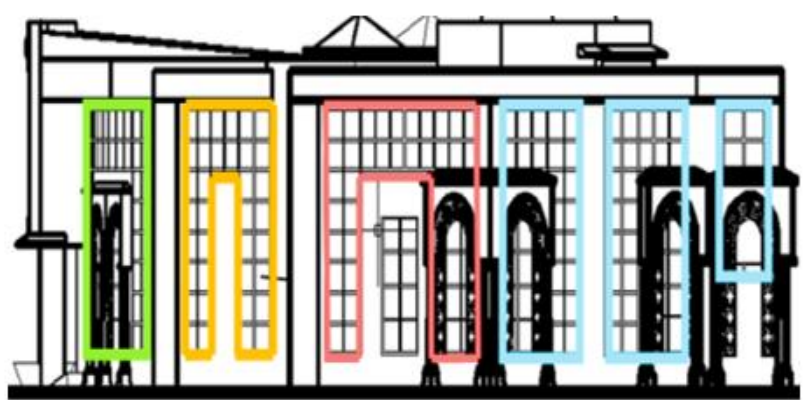

(b)Lateral façade.

\begin{tabular}{|l|l|l|l|l|l|}
\hline $40 \mathrm{~m}^{2}$ & $110 \mathrm{~m}^{2}$ & $62.4 \mathrm{~m}^{2}$ & $\square 13.6 \mathrm{~m}^{2}$ & $71.8 \mathrm{~m}^{2}$ & $58 \mathrm{~m}^{2}$ \\
\hline
\end{tabular}

Fig. 14: The BIPV general surfaces in the main facade of the study project, by authors.

\subsection{Sizing the BIPV solution}

To size the BIPV system, a methodology is adapted as follows:

1. The evaluation of the electrical energy needs Average Daily Consumption (ADC) of users,

2. Measure or estimate the daily and annual solar irradiation received at the site of implantation,

3. Define the energy requirement of the installation (DC and AC Loads),

4. Calculated the size of the PV generator,

5. If the BIPV is standalone it could be having a storage system,

6. If the BIPV is Grid connected it must be having a Grid-connected inverter,

7. If the BIPV is Grid connected with storage, the capacity of storage must be calculated.

8. Calculate The cost of the BIPV, for different panels inclination

The following flowchart in figure 15 represents the adopt methodology: 
(online) $=$ ISSN $2285-3642$

ISSN-L = $2285-3642$

Journal of Economic Development, Environment and People

Volume 9, Issue 1, 2020

URL: http://jedep.spiruharet.ro

e-mail: office jedep@spiruharet.ro

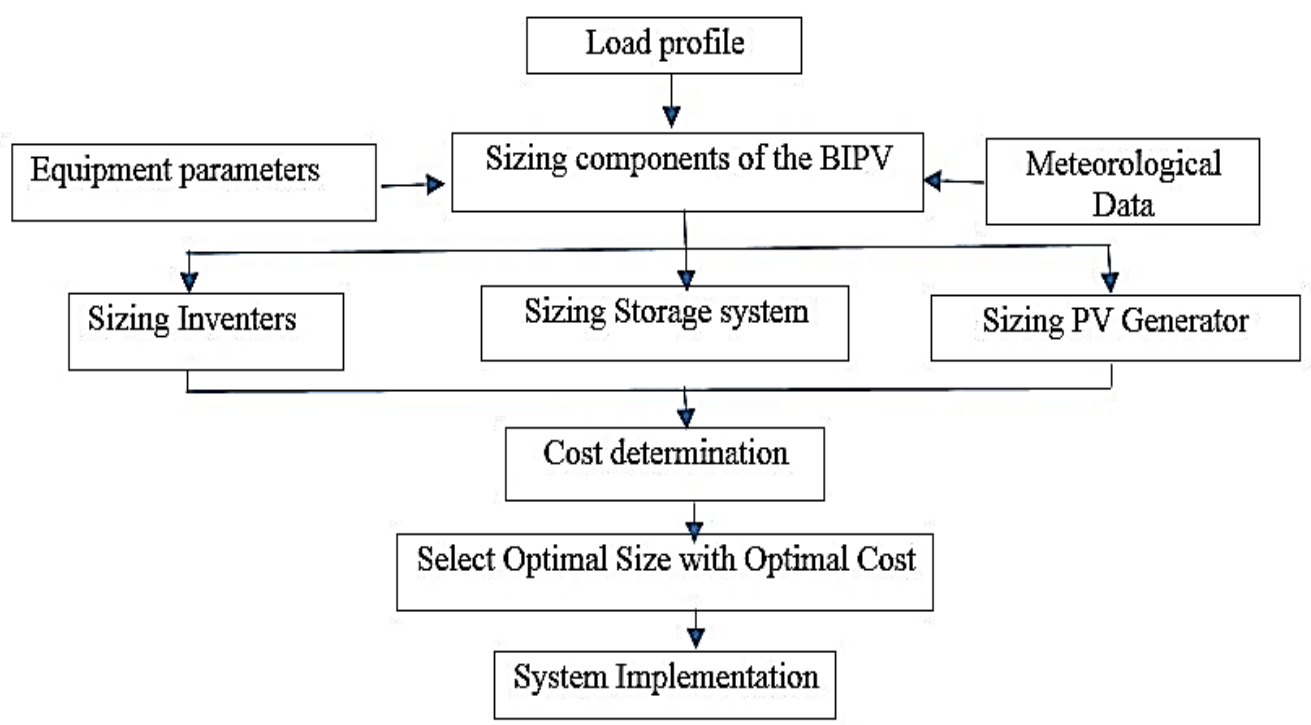

Fig. 15: The adopt methodology flowchart, by authors.

\section{Results and discussion}

In this section the results are presented and have been discussed.

\subsection{Grid Interaction}

\subsubsection{Energy Consumption}

Inside highly glazed modern buildings, achieving good comfort is often at the cost of high-energy consumption. Table 3 gives us information on the values of daily electricity consumption "Days per week", and the energy that it is consumed by appliances, lamps, air conditioners also, according to the table below, our equipment needs $2161.2 \mathrm{kWh}$ of energies in a month. Therefore, the annual energy consumption has an estimated 25934,4 kWh/year.

Table 3. Daily electricity consumption "days per week" in the study project.

\begin{tabular}{|c|c|c|c|c|}
\hline Use 5 days a week & Number & Power & hourly use & $\begin{array}{c}\text { Energy } \\
\text { Wh/Day }\end{array}$ \\
\hline Lamps (LED) & 66 & $30 \mathrm{~W} /$ Lamp & $1 \mathrm{~h} /$ jour & 1980 \\
Computer & 15 & $120 \mathrm{~W} /$ apparatus & $4 \mathrm{~h} /$ jour & 7200 \\
Phone & 14 & $3 \mathrm{~W} /$ apparatus & $6 \mathrm{~h} /$ jour & 252 \\
Conditioner & 32 & $1000 \mathrm{~W} /$ apparatus & $3 \mathrm{Wh} /$ jour & 96000 \\
Modem & 01 & $5 \mathrm{~W}$ tot & $6 \mathrm{~h} /$ jour & 30 \\
Printer & 12 & $10 \mathrm{Wtot}$ & $1 \mathrm{~h} /$ jour & 60 \\
\hline Total daily energy & \multicolumn{4}{|c|}{$105.522 \mathrm{~h} /$ Day } \\
\hline
\end{tabular}




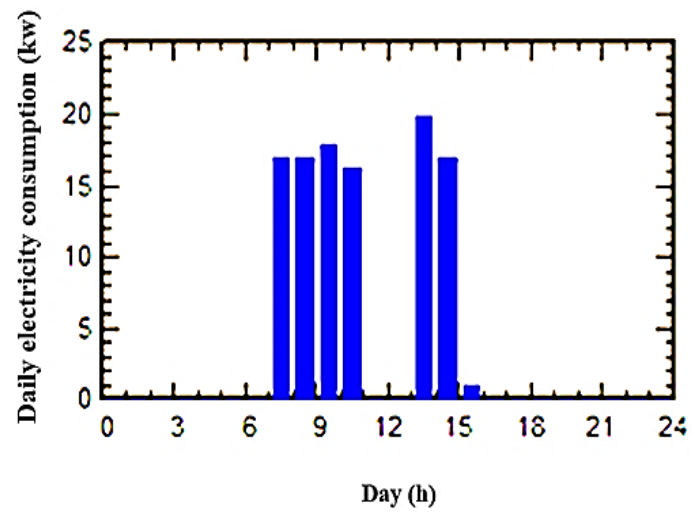

Fig. 16: Daily Load Profile.

\subsubsection{Photovoltaic Generator Sizing}

The fundamental equation describes the PV power generation are:

$P_{P V}=\eta_{p v g} \cdot A_{p v g} \cdot G_{i r}$

With $A_{p v g}\left(\mathrm{~m}^{2}\right)$ is the surface of PV generator, ${ }^{p v g}$ the efficiency of conversion, given by:

$\eta_{p v g}=\eta_{r} \cdot\left[1-\beta .\left(T_{c}-T_{c r e f}\right)\right]$

$\eta_{r}:$

Photovoltaic module reference efficiency.

B: Temperature coefficient which supposed constant for silicon solar cells.

$\boldsymbol{T}_{\text {cref }}:$ Tcref Reference solar cell temperature $\left({ }^{\circ} \mathrm{C}\right)$.

$\boldsymbol{G}_{\text {ir }}$ : Global solar irradiation $\left(\mathrm{W} / \mathrm{m}^{2}\right)$.

$\boldsymbol{T}_{\boldsymbol{c}}$ : Solar cell temperature it gives by:

$T_{c}=T_{a}+\left(\frac{N O C T-20}{800}\right) \cdot G_{i r}$

The size of PVG (PV generator) is the area (surface) occupied by a number of modules mounted in series and in parallel, to satisfy the energy needs of the user.

$A_{p v g}=$ NMS .NMP. Scell

$\mathrm{NMS}=\frac{V_{\text {inst }}}{V_{\text {MNom }}}$

Considering efficiency of storage batteries and the inverter $\eta_{b}$ and $\eta_{i}$ respectively, the efficiency of the photovoltaic system is given by the following equation:

$\eta_{\text {inst }}=\eta_{p v g} \cdot \eta_{b} \cdot \eta_{i}$

$\mathrm{NMP}=\left(F S \cdot \frac{C J M}{I R G M \cdot \eta_{p v g} \cdot \eta_{b} \cdot \eta_{i} \cdot S_{c e l} \cdot N M S}\right)$

NMS: Number of modules in series.

NMP: Number of parallel modules.

After Appling the behavior calculate the size and the characteristics of photovoltaic generator according to the inclining degrees $31^{\circ}$ and $90^{\circ}$ is given in the following table: 
(online) $=$ ISSN $2285-3642$

ISSN-L = $2285-3642$

Journal of Economic Development, Environment and People

Volume 9, Issue 1, 2020

URL: http://jedep.spiruharet.ro

e-mail: office jedep@spiruharet.ro

Table 4. Generator comparison table between the two case studies.

\begin{tabular}{|c|c|c|}
\hline & ${\text { PVG inclined with } \mathbf{3 1}^{\circ}}^{\circ}$ & ${\text { PVG inclined with } \mathbf{9 0}^{\circ}}^{\mathbf{0}}$ \\
\hline The number of PV modules & 02 serial & 02 serial \\
\hline Unit power & $285 \mathrm{Wc}$ & $285 \mathrm{Wc}$ \\
\hline Number of modules & 78 & 172 \\
\hline AC nominal power & $19.6 \mathrm{kWc}$ & $86 \mathrm{kWc}$ \\
\hline The number of PV chains & 39 & $301 \mathrm{~m}^{\mathbf{2}}$ \\
\hline Surface cells & $136 \mathrm{~m}^{\mathbf{2}}$ & $343 \mathrm{~m}^{2}$ \\
\hline Surface modules & $151 \mathrm{~m}^{\mathbf{2}}$ & $27 \mathrm{~kg}$ \\
\hline Panel size & $1.956 \times 0.992 \times 0.05$ & $1.956 \times 0.992 \times 0.05$ \\
\hline Weight & $27 \mathrm{~kg}$ & 25 Years \\
\hline Life time & 25 Years & \\
\hline
\end{tabular}

6.2. Load Matching Analysis

6.2.1. The capacity of energy storage sizing

To sizing the capacity of storage, in this work the following method is adopted:

1. Calculate the average daily consumption (ADC),

2. Determine the number of days of autonomy $\left(\mathrm{J}_{\text {aut }}\right)$,

3. Determine the maximum acceptable discharge depth $\left(D_{m}\right)$ by the battery according to the type of battery used,

4. Calculate the capacity of the battery $C_{\text {acc }}$ using the following equation:

$$
\begin{aligned}
& C_{a c c}=\frac{A D C \cdot D_{a u t o}}{V_{b} \cdot \eta_{a c c} \cdot D_{m}} \\
& \mathrm{NB}=\frac{C_{a c c}}{C_{b}}
\end{aligned}
$$

$\mathrm{NBP}=\frac{N B}{N B S}$

$\mathrm{NBS}=\frac{V_{\text {inst }}}{V_{a c c}}$

$D_{\text {acc }}$ : Battery capacity of storage, (Ah).

ADC: Average daily consumption, $\left(\mathrm{Wh} / \mathrm{m}^{2}\right)$.

$D_{\text {aut }}$ : Days of autonomy, (J).

$\boldsymbol{D}_{\boldsymbol{m}}$ : $\quad$ Deep discharge of the battery.

$V_{\text {Inst }}$ : Installation voltage, (V).

$\boldsymbol{C}_{\boldsymbol{b}}$ : Cost of the battery.

NB: Total number of batteries.

NBP: Number of batteries in parallel.

NBS: Number of batteries in series. 


\author{
(online) $=$ ISSN $2285-3642$ \\ ISSN-L = $2285-3642$ \\ Journal of Economic Development, Environment and People \\ Volume 9, Issue 1, 2020 \\ URL: http://jedep.spiruharet.ro \\ e-mail: office jedep@spiruharet.ro
}

Table 5. Storage battery comparison table between the two case studies.

\begin{tabular}{|c|c|c|}
\hline & PVG inclined with 31 & PVG inclined with $\mathbf{9 0}^{\circ}$ \\
\hline Type of batteries & $12 \mathrm{~V} / 160 \mathrm{Ah}$ & $12 \mathrm{~V} / 160 \mathrm{Ah}$ \\
\hline Number of batteries & $72(4$ series $\times 18$ in parallel). & 130 (5 serial x 26 parallel) \\
\hline V $_{\text {nom }}$ & $48 \mathrm{~V}$ & $48 \mathrm{~V}$ \\
\hline Capacity & $3024 \mathrm{Ah}$. & $4160 \mathrm{Ah}$ \\
\hline Temperature & $25^{\circ} \mathrm{C}$ & $25^{\circ} \mathrm{C}$ \\
\hline Weight & $75 \mathrm{~kg}$ & $75 \mathrm{~kg}$ \\
\hline
\end{tabular}

Converting the direct DC current produced by the photovoltaic generator into AC current. The inverter has the following electrical characteristics:

Table 6. Photovoltaic solar inverter comparison table between the two case studies.

\begin{tabular}{|c|c|c|}
\hline & PVG inclined with 31 & PVG inclined with $\mathbf{9 0}^{\circ}$ \\
\hline Overall power between & $49 \mathrm{~kW}$ & $49 \mathrm{Kw}$ \\
\hline Operating voltage & $48 \mathrm{~V}$ & $60 \mathrm{~V}$ \\
\hline Minimum input voltage & $30.7 \mathrm{~V}$ & $58.2 \mathrm{~V}$ \\
\hline Maximum input voltage & $50.4 \mathrm{~V}$ & $66.7 \mathrm{~V}$ \\
\hline
\end{tabular}

\title{
6.2.2. Energy Generation
}

The available power produced by the system in the first case (BIPV in the facade) is $61.59 \mathrm{Mwh} /$ year. The available power produced by the system in the second case (above the roof of the building) is estimated at $44.65 \mathrm{MWh} /$ year. The system, in this case, is less productive than the first case. The available energy produced by the system is divided into three types:

- Energy consumed by the building, which covers all the energy needs of the building.

- Excess energy, stored in the battery used when needed or pumped into the public network.

Finally, lost energy, resulting from the effects of climate like the effect of dust and temperature on the performance of the panels. The type and nature of the system used and methods of installation, also played a very effective role in the degree of energy lost. Whenever the system was well installed in a professional manner. Whenever decreased the amount of lost energy. And improved the efficiency and performance of the system (See Table.4.5.6).

The role of the battery in the solar panel system is the storage of unused excess energy, and use when needed. Unused energy "full battery" in the vertical installation of panels in façade is $32.84 \mathrm{MWh} /$ year. It is greater compared than the energy stored in the second case, that is when solar panels are placed above the roof at an angle of $31^{\circ}$. Which evaluated $15.21 \mathrm{MWh}$ /year. But the most remarkable thing (c.f., Fig. 17), that batteries are discharged during the summer. This is due to the excessive use of the air conditioner during the months, (May-June -July). Notice that the battery is discharged considerably in that period, to cover needs energy for air conditioning. To make a big investment in energy. We must think about selling surplus energy to the government. Because the Algerian government is working hard to encourage investment in renewable energy in general. This solution helps us to: Firstly, we can reduce the number of batteries. Secondly, the administrative structure does not work at night. Therefore, we can pump unused surplus energy into the public power grid. And sell it at a price three times. So, this is a very important economic benefit (energy injected into the networks). 


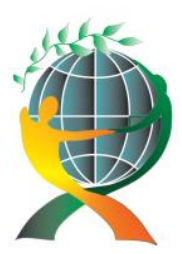

(online) $=$ ISSN $2285-3642$

ISSN-L = 2285 - 3642

Journal of Economic Development, Environment and People

Volume 9, Issue 1, 2020

URL: http://jedep.spiruharet.ro

e-mail: office jedep@spiruharet.ro

Standardized production (per KKp Installed) Rated power 22.23

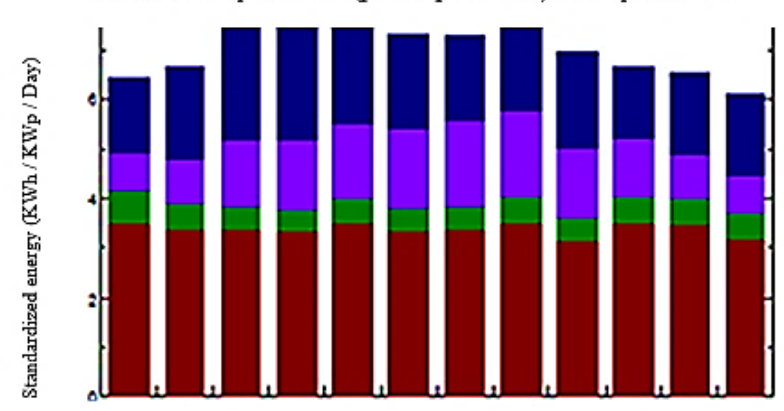

Jan Feb Mar Apr May June July Aug Sep Oet Nvb Dec

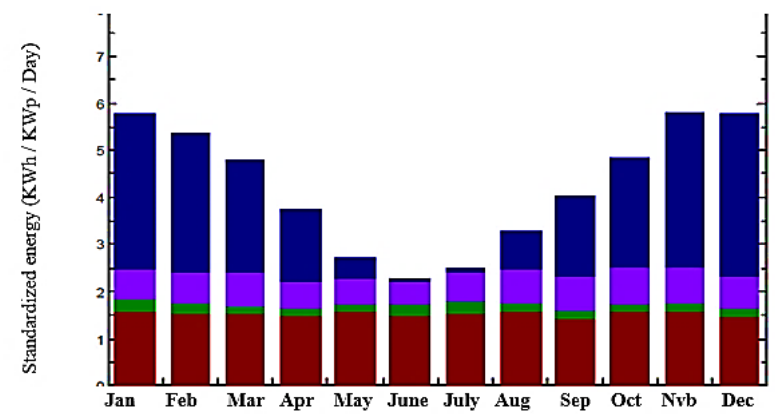

$\square$ Lu: Unused energy (Plain Battery) $1.84 \mathrm{Kwh} / \mathrm{kWp} /$ day.

Lo: Loss of collection (PV field) $\quad 0.66 \mathrm{Kwh} / \mathrm{kWp} / \mathrm{day}$.

Ls: System loss and battery charge $0.19 \mathrm{Kwh} / \mathrm{kW} / \mathrm{day}$.

$\square$ Ye: Energy provided to the user $1.54 \mathrm{Kwh} / \mathrm{kWp} /$ day.

Lo: Loss of collection (PV field) $1.27 \mathrm{Kwh} / \mathrm{kWp} /$ day.

Ls: System loss and battery charge $0.51 \mathrm{Kwh} / \mathrm{kWp} /$ day.

Ye: Energy provided to the user $3.39 \mathrm{Kwh} / \mathrm{kW} / \mathrm{p} /$ day.

(b) the case of $90^{\circ}$.

(a) the case of $31^{\circ}$.

Fig. 17: Standardized production per kWc installed.

Table 7. PV solar inverter comparison table between the two case studies.

\begin{tabular}{|c|c|c|}
\hline & PVG inclined with 31 $^{\circ}$ & PVG inclined with $\mathbf{9 0}^{\circ}$ \\
\hline Nominal power & $22.23 \mathrm{kWc}$ & $49 \mathrm{KWc}$ \\
\hline The available energy & $44.65 \mathrm{MWh} /$ year. & $61.59 \mathrm{Mwh} /$ year \\
\hline The energy used & $27.54 \mathrm{MWh} /$ year & $27.54 \mathrm{MWh} /$ year \\
\hline Energy (unused) & $15.21 \mathrm{MWh} /$ year & $32.84 \mathrm{MWh} /$ year \\
\hline
\end{tabular}

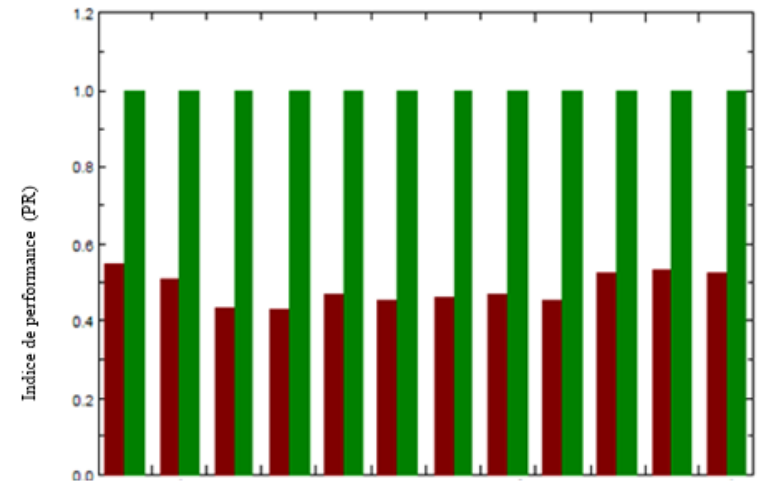

Jan Feb Mar Apr May June July Aug Sep Oct Nvb Dec

SR: Performance Index (PR) Yf /Yr: $\mathbf{0 . 4 8 2}$

SF: Performance Index (PR) Esol / E Load: 1.000

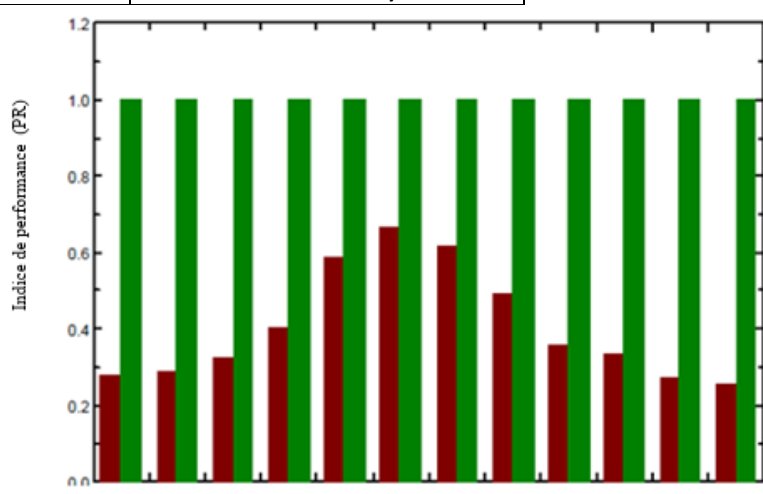

Jan Feb Mar Apr May June July Aug Sep Oct Nvb Dec

SR: Performance Index (PR) Yf $/$ Yr: 0.365

SF: Performance Index (PR) Esol / E Load: 1.000

$E_{\text {Miss }}$ Energy Missing; $E_{\text {user }}$ Energy provided to the user; $E_{\text {Load }}$ User's energy need; $\boldsymbol{E}_{\text {Miss }}=\boldsymbol{E}_{\text {Load }}$ - $\boldsymbol{E}_{\text {user }}$. (a) The case of $31^{\circ}(P R)=48.16 \%, S F=100 \%$.

(b) The case of $90^{\circ}(P R) 36.46 \%, S F=100 \%$.

Fig. 18: Performance index (PR), and solar fraction (SF).

\subsection{Economic Analysis}

\subsubsection{The cost of installation}

In order to be sure if our system is economically successful or not! From the simulation results, it can be defining the Total Cost (TC) of a PV installation, like the following model: 


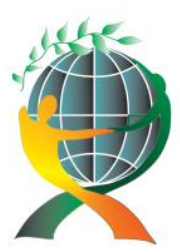

\author{
(online) $=$ ISSN $2285-3642$ \\ ISSN-L = 2285 - 3642 \\ Journal of Economic Development, Environment and People \\ Volume 9, Issue 1, 2020 \\ URL: http://jedep.spiruharet.ro \\ e-mail: office jedep@spiruharet.ro
}

In this work, to calculate the cost of the installation, a simplify method is applied as following:

$$
T C=C_{G P V}+C_{S}+C_{r e g}+C_{i n v}+C_{0}
$$

While the cost price in $\mathrm{kWh}$ of the PV system is given by:

$$
C_{\mathrm{PVkWh}}=\frac{T C L F}{T_{\text {cons }}}
$$

And (TCLF) represents the Total Estimated Cost for a Lifetime of installation notice, given by:

$$
T C L F=T C+C O M+C R B
$$

- We calculated the Total Cost of the components (TC), of the system producing electrical energy in the building. Such as (Battery Panel- Regulator- Inverter Off gird- Price of installation of the system-The price of the cleaning -Price of maintenance- Price of renewing batteries due to damage). This study included two cases: The first case and the second case, in a lifetime approximate 25 years. The second case was estimated at $35,997.71$, less than in the first case which was an amount determined by 73836,8 $\$$ (see Relationship 12). The total cost provided in this system (see relationship 14) was $113877.90 €$ in the first case, while $58164.90 €$ in the second case. In the third case, the total cost of energy consumed by the building per year (fossil and non-renewable source of energy) is estimated at $3371,472 €$, and $84286.8 €$ for 25 years (c.f., Fig. 19). The installation of the system in the facade in the first case study produced approximately $61590 \mathrm{kWh} /$ year. and $44650 \mathrm{kWh} /$ year for the second case.

- The available energy consists of energy used by the building (i), which is estimated at $25934.4 \mathrm{kWh} /$ year. And other energy (unused), energy injected into the network (ii), which is estimated to $32840 \mathrm{kWh} /$ year for the first case, and $15210 \mathrm{kWh} /$ year for the second case.

\title{
6.3.2. The Comparative Techno-Economic Feasibility
}

It is necessary to estimate the economic performance of our case study, we conducted a comparative study, between three case studies:

- First case: The system BIPV is installed in the facades of the building, (inclination angle $90^{\circ}$ ).

- Second case: The system BIPV is installed on the roof of the building, (inclination angle B $31^{\circ}$ ).

- Third case: The building in its current state, (the use of non-renewable fossil energy. The electrical needs of this equipment estimated at $25934,4 \mathrm{kWh} /$ year).

In this work, we have used some indicators to evaluate the techno-economic performance of the BIPV, as well as the performance of the battery. We have summarized our study in the table below (See TABLE.9).

This table presents the results of the detailed analysis of energy budgeting used in our system. The Payback Period (PP), Internal Rate of Return (IRR), Net Present Value (NPV), in order to evaluate the economic efficiency of BIPV in administrative equipment.

i.) The Payback Period (PP): It is an indicator of the time period over which a project is expected to recover its initial investment. It uses the liquidity it provides, which is determined based on total initial costs, total yearly savings, and total yearly costs (but excluding all debt payments). The basic requirement for recovery inclusion is that the smaller the payback period, the more beneficial the project is to investors.

ii.) Internal Rate of Return (IRR): It is the interest earned, i.e. the time-adjusted rate of return by the Project equity over the life of the project. It is determined by checking the discount value that would reduce the net present value of a project to zero. A project with an IRR greater than or equal to the discount rate is considered to be sustainable. The IRR calculates the return on the initial investment and is determined by an iterative process that includes selecting a discount rate (DR) and discounting the cash flow until the net value of the investment is zero.

iii.) Net Present Value (NPV): Investing in a positive NPV will be cost-effective and a profitable one. In addition, the greater the NPV of the project, the more benefits. NPV measures the value of a project by taking into account all future cash flows that are discounted at the discount rate. NPV is a measurement of accumulated profit calculated by subtracting the present values of the cash payments (including the initial cost) from the current 


$$
\begin{gathered}
\text { (online) }=\text { ISSN } 2285-3642 \\
\text { ISSN-L = 2285 - } 3642
\end{gathered}
$$

Journal of Economic Development, Environment and People

Volume 9, Issue 1, 2020

URL: http://jedep.spiruharet.ro

e-mail: office jedep@spiruharet.ro

values of the cash inflows over the lifetime of the PV installation. The NPV can be used to show the net difference between the benefits and costs of an energy system compared to an alternative in present or annual values, and is calculated by the difference between the present value of benefits and the present value of costs.

iv.) Other Financial Parameters: Other financial parameters such as the energy production cost, annual life cycle savings and the cost-benefit ratio are included in this study. The benefit-cost ratio (B-C) is an economical ratio that consists of the net benefits to the costs of the project (Bamisile, Olubiyo, Dagbasi, Adun, \& Wole-Osho, 2019).

Table 8. Summary of the economic evaluation of the typical case study

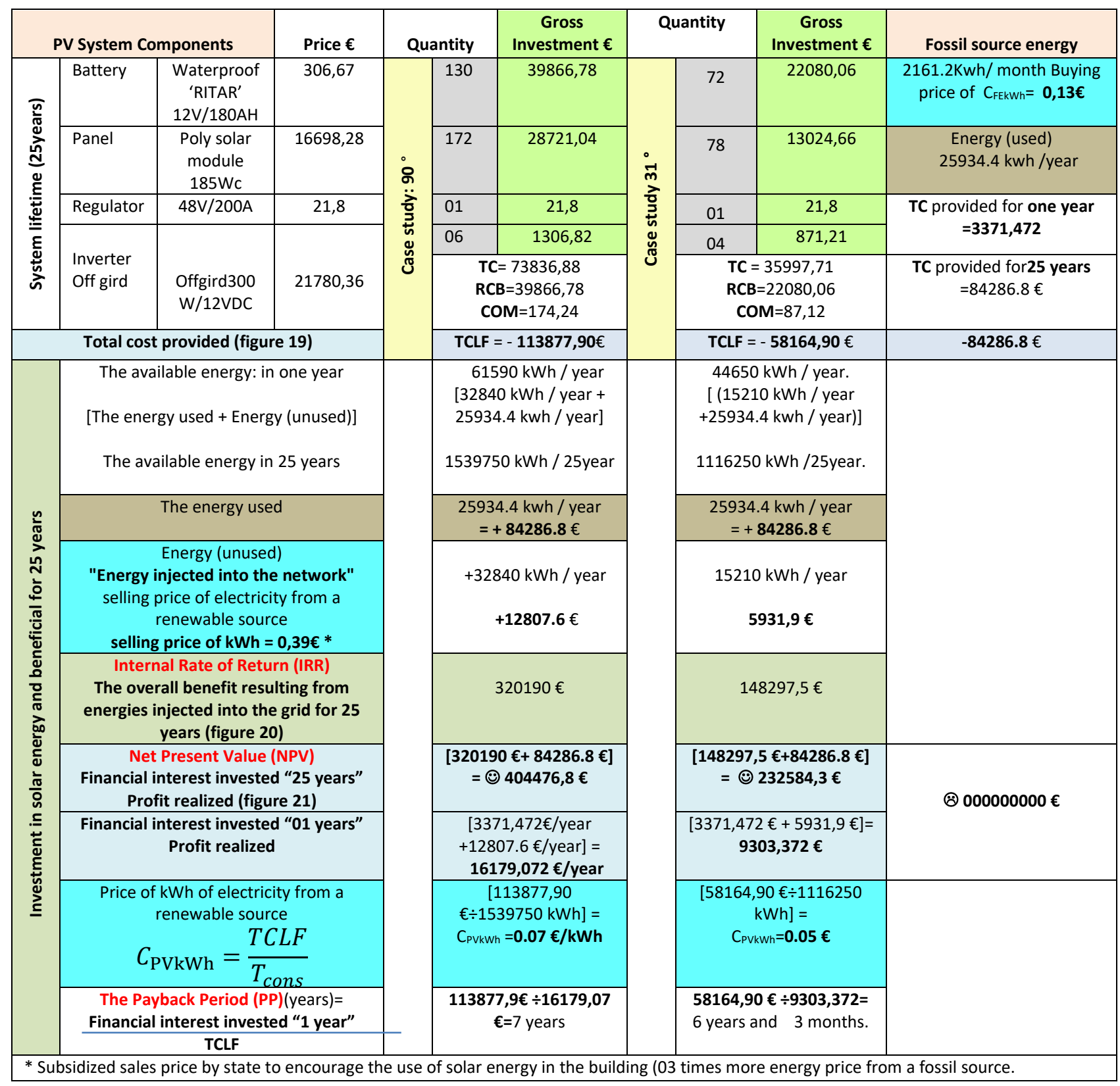




\subsubsection{The estimated total cost for a lifetime of the installation notice PV and the total cost provided for fossil electricity}

Figure 19, Shows the results of the comparative study, to illustrate the benefits of integrating PV systems into buildings. The first bar indicates (TCLF) the Total Estimated Cost for a Lifetime of the installation notices for an integrated PV system on the facade (BIPV). Which was the most expensive cost with 113877,90€ compared to (TCLF) of PV that has been installed on the roof that appears in the second bar of the diagram.

The (TCLF) of PV install on the roof is the cheapest price, with half the cost of the first integration until $58164,90 €$. But, the estimated total cost of electricity from a fossil source for 25 years is more expensive of a hardware installation provided for roof installation. And less expensive (TCLF) vertically integrated on the facade with a total cost evaluated from $84286.8 €$.

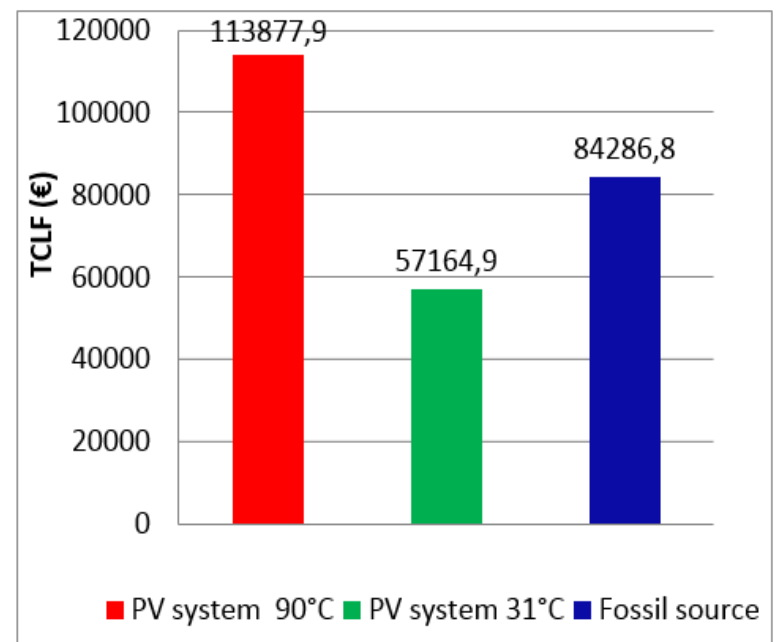

Fig. 19: The diagram of the estimated total cost for a lifetime of the installation notice PV and the total cost provided for fossil electricity, by authors.

\subsubsection{Internal Rate of Return (IRR): The overall profit resulting from the sale of PV energies injected into the public network for 25 years}

The integrated PV panel system in the facade can fully produce up to $1539750 \mathrm{~kW}$ in the 25 years. And $61590 \mathrm{kWh} /$ year, which is divided into $25934.4 \mathrm{kWh} /$ year (usable energy in the equipment) and 32840 $\mathrm{kWh} /$ year energy stored in batteries (no-used energy). The integrated PV panels system in the facade can fully produce up to $1539750 \mathrm{kWh}$ in the 25 years. And $61590 \mathrm{kWh} / \mathrm{year}$ which is divided into 25934.4 $\mathrm{kWh}$ /year (usable energy in equipment) and $32840 \mathrm{kWh} /$ year energy stored in batteries (no-used energy). The second installation on the roof has a total electricity production capacity of $1116250 \mathrm{kWh}$ for $25 y$ year and $44650 \mathrm{kWh} /$ year. Therefore $15210 \mathrm{kWh} /$ year of stored energy or (no-used energy). Since our equipment operates 6-7 hours a day permanently (c.f., Fig. 16). So, it does not need electricity except in the morning. This allows us to inject surplus output into the public grid, and invest in the draft state plan to encourage the production and sale of energy from a green source. Where the price of electricity up to 03 times weakness (the price of $\mathrm{kWh}=0,39 €$ ) compared to the price of electricity from a fossil source (price per $\mathrm{kWh}$ $\boldsymbol{C}_{\mathbf{P V k W h}}=0.13 €$ ). To recover our planned budget for the installation of $\mathrm{PV}$ in our equipment in the near future. We propose to sell electricity to the state. But what is the most profitable system on the roof or in the facade? 
Columns in (c.f., Fig. 20) represent total economic benefits and profits produced by integrating solar panels into the building. Resulting from the sale of PV energies injected into the public grid for 25 years. In the first case, PV systems are on the façade can reach 320190 euros. These profits are derived from the electrical power that is pumped into public networks, which were sold to the government at a price of three times per unit (selling price of $\mathrm{kWh}=0,39 €$ ). From the system of the second case study, which was installed on a roof with $31^{\circ}$ estimated at about $148297,5 €$ of the total profits of the energies, coming from the sale of the electrical energy that is pumped in the public networks. On the other hand, the consumption of fossil energies is not returning any investment $0 €$. On the contrary, they consume a considerable amount and do not achieve any benefit or profit for 25 years, the amount disbursed during this period may reach $84286.8 €$ (See table 08).

Finally, concludes that it is true that the total amount spent on the purchase and installation of the system on the facades is very high compared to the installation above the roof. However, the profit and interest earned during the 25 years in the first case twice the interest earned in the second case. The latter case, which is unprofitable on the contrary, consumes a huge amount of money in addition to its negative impact on the environment.

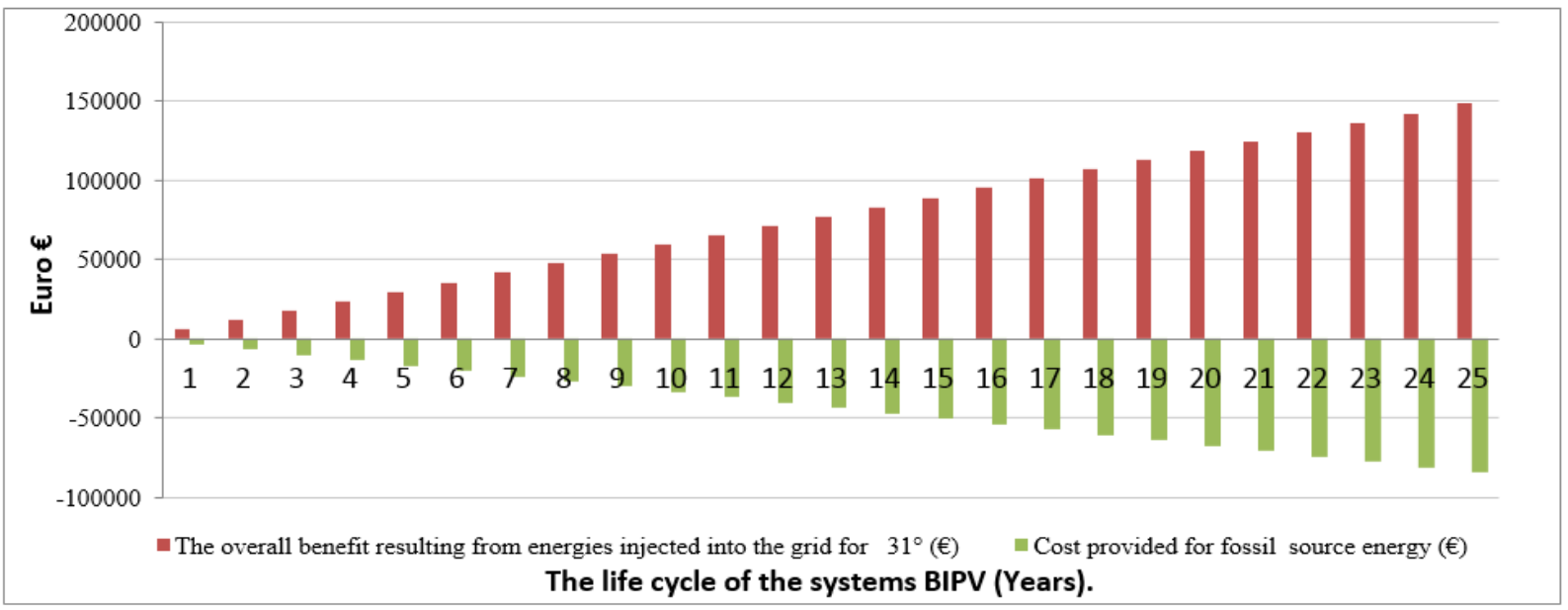

Fig. 20: The diagram of the overall profit resulting from the sale of PV energies injected into the public network for 25 years, by authors.

\subsubsection{Net Present Value (NPV): The total financial interest invests a PV facility in ' 25 years' and the cost provided of fossil source energy}

In addition to the profit from the sale of electricity to the government and pumping it into the public grid, another profit is the energy used by the building for 25 years. The installed solar panels can cover the building's electricity needs for 25 years, which are estimated at $84,286.8 €$. Thus, the total benefit gained from this system over 25 years is the total price of energy sold in the network throughout 25 years, plus the total price of energy needed by the building for 25 years. Which is estimated to be $404476,8 €$ for the system BIPV in the facades and issued in $232584,3 €$ for the system on the roof (c.f., fig. 21). Calculates the raw unitary price real for the electrical unit, in each case. We must divide the total amount spent on each system. It was $113877,90 €$ and $58164,90 €$ in the first and second case respectively. We divide it by the total energy produced for 25 years in each system. Which were $1539750 \mathrm{kWh} / 25 y e a r$ in the first case and $1116250 \mathrm{kWh}$ (see Table.8). In the end, the price is $\boldsymbol{C}_{\mathbf{P V k W h}}=0.07 €$ for the system BIPV on the façade of the building, it was half cost of kWh electricity from a fossil source, and $\boldsymbol{C}_{\mathbf{P V k W h}}=0.05 €$ for the system BIPV on the roof, it was 
One-third the price cost of kWh electricity from a fossil source. The formula for the calculation of unit electricity Price of kWh of electricity from a renewable source is given by relation number 13 .

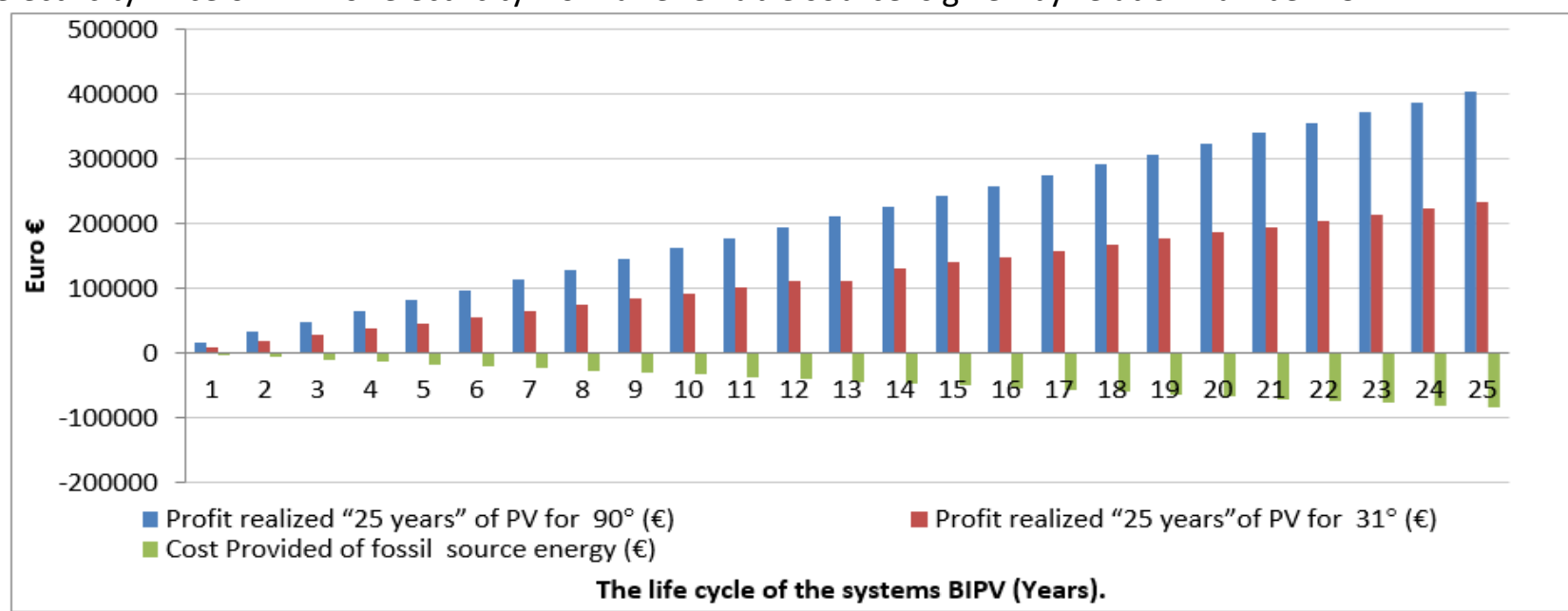

Fig. 21: The total financial interest invests a PV facility in "25 years" and the cost provided of fossil source energy, by authors.

\subsubsection{The Payback Period (PP) of the system BIPV}

The Payback Period (PP) is the sufficient period to recover the disbursed amounts in the purchase of the system's hardware, installation and maintenance. We divide the total cost of the system by the financial interest invested in one year (Profit realized) of the system. Which is estimated at $16179,072 €$ /year in the first case. The $9303,372 €$ in the second case. To find that, the duration needed to compensate the amount spent on the installed BIPV system in the facade is 7 years. While 6 years and 3 months for the system BIPV placed in the roof. Therefore, since this system has a life span of 25 years, it can be said to be an economically efficient and successful project. Because It manages excellent profits after the expiration of the refund period spent in the operation and installation of this system. And socially profitable, because this system guarantees us a modern architecture, contemporary, beautiful and attractive. It satisfies the desire of citizens and their requests, according to this our field investigation. With the benefit of solar energy and tamed in the service of clean architecture. In addition, the importance of BIPV in protecting the environment from pollution caused by non-renewable energy sources.

\section{The implementation of BIPV integration (cases studies)}

Often, the success of the architect in the design of the outer shell of architecture guarantees him a large percentage of the success of the project itself. So, he should pay great attention to choosing modern materials and attractive colors in his conception. Because he is the first and last responsible in the success of his project or failure. Glass is among the most attractive building materials since ancient times. Since contemporary architecture invaded administrative buildings in a remarkable way. So, we had to replace ordinary glass with intelligent energy-producing glass, and more attractive on the other hand. And according to our comparative studies of benefits, the economics of BIPV. We will now conduct a comparative study regarding the aesthetic effect of the system BIPV. This is between the two cases. In the first case, the system is installed on the interface. The second case, the system is installed above the roof.

\subsection{First possibility of integration: BIPV integration in curtain facades}

Curtain walls: A wall that provides no significant structural support beyond what is necessary to bear its own materials or conduct such loads to a load-bearing wall. Currently most popular, design facades 
independently from the structure using a lot of glass, usually as a panel cladding (curtain wall). Many studies indicate that the building geometry and the BIPV location within the building facade have an important impact on the BIPV temperature, with possible implications concerning long-term degradation. Also, the fixing method has a very essential role in the performance of the panels. BIPV can take the place of a fixed panel on the secondary framework, networks which can be located in the thickest of uprights and sleepers (c.f., Fig. 22). We are observed in this installation process. It is very easy and quick, light, and it is inexpensive and increases the attractiveness of the building.
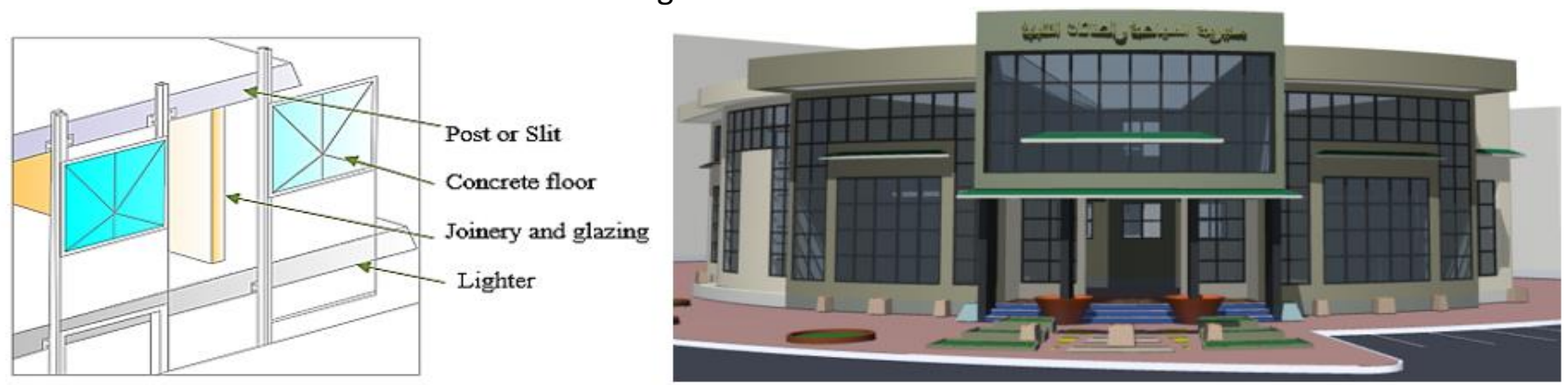

Fig. 22: Representative of BIPV integration in curtain facades, by authors.

\subsection{Second possibility of integration: BIPV integration in glazed facades}

The use of glass BIPV modules is continually improving due to the detail that they can replace almost every conventional material of the building envelope and they can actively donate to the building energy balance. Along with the multifunctionality of the building skin, BIPV currently involves a new aesthetics in contemporary architecture. Thanks to innovative possibilities in glass advance and customization for BIPV solution, a wide range of architectural languages arises in current requests, extending from the visible semantics of solar cells to the technological imitation.

This type of facade admits to facilitating the assembly and disassembly of a BIPV sensor that would be fixed between the heads of the window carpentry. BIPV is placed separately from the facade as isolated from the structure, usually is placed either inside or from the outside to preserve the architectural aspect (aesthetic). The integration of BIPV into the glazing is feasible. The double-glazing present could be upset by the BIPV glazing. Networks can be placed in hollow steel sleepers and even on hoods (c.f., Fig. 23). The implementation would be easy and simple and the maintenance would be fast and very simple and easy. However, the tightness between the joints (the seals) of the BIPV panels must be guaranteed by the hoods of the joinery. So, would allow the architect to create various compositions and architectural designs and aesthetically very pleasant.
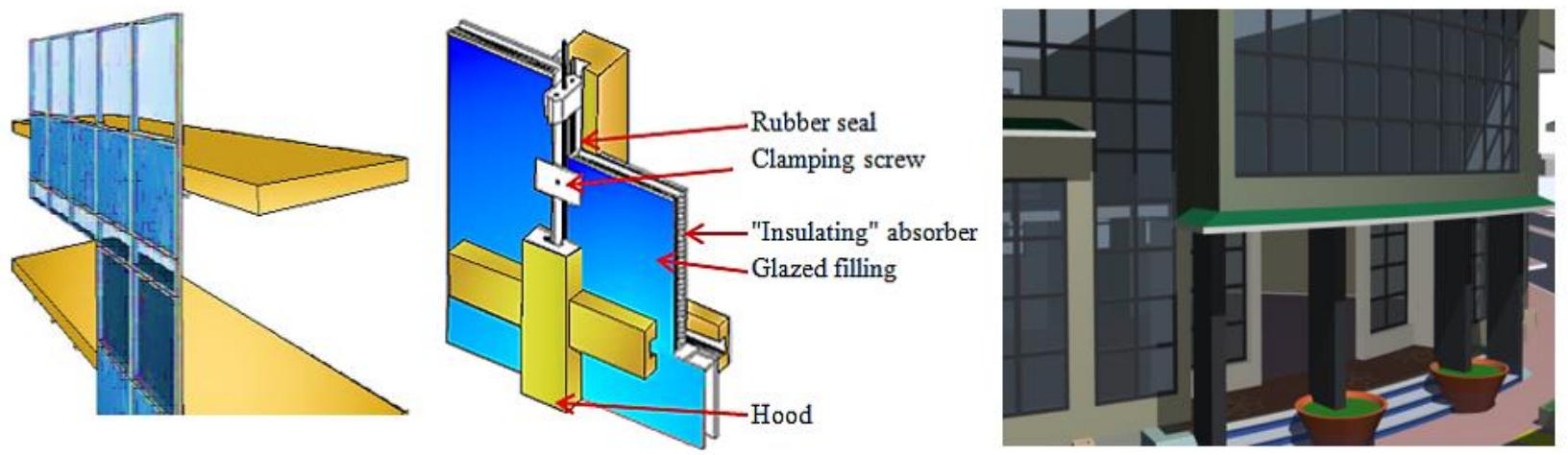

Fig. 23: Representative of BIPV integration in curtain wall associating glazing and panel, by authors. 
URL: http://jedep.spiruharet.ro e-mail: office jedep@spiruharet.ro

\subsection{PV integrations on roof}

When we installed the solar panels above the roof at an angle of 31 degrees, it produced maximum electrical power. However, these solar panels distorted the facade of the building. And it affected the aesthetic and artistic sense of architecture. And reduce the attractiveness of the building. In addition, the weight of the system on roof negatively affects the structure, its resistance to the building and thus its lifetime of this building (c.f., fig. 24).
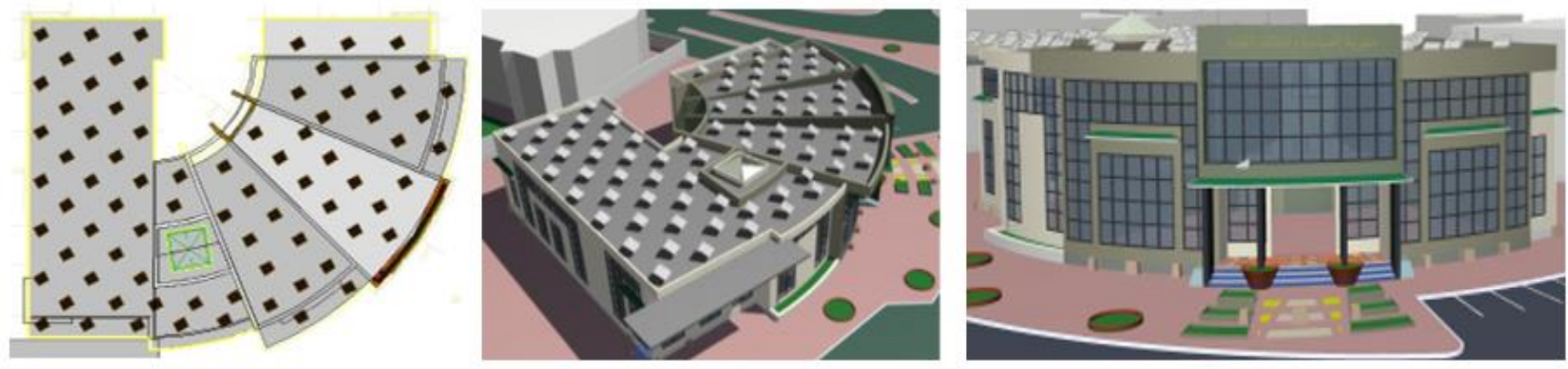

Fig. 24: Poor visual impact (the absence of aesthetic) for the installation of photovoltaic panels $\left(31^{\circ}\right)$ on the roof, by authors.

\section{Conclusion}

In this work, a review of the literature on the BIPV system has been conducted to recognize the different ways of strategies, modes, and techniques that are recently used. As an example, we have taken administrative equipment located in the semi-arid region. A comparative study between two sets of angles and positions (i.e., $90^{\circ}$ vertical and $31^{\circ}$ tilt) to define the tilting impact of the panels on the economic side, aesthetic aspect, efficiency energy. Moreover, a detailed study is conducted to determine the optimal design of the BIPV system for an office building. This work has demonstrated that BIPV systems can generate a huge quantity of clean green energy from a renewable and equitable solar source while being part of the energyefficient building facade. Furthermore, the panels integrated on facades can play multifunctional roles as ordinary building components elements, ensuring other aesthetic functions. Also, this work has proven that the use of a PV system integrated on facades can recover the provided purchase and installation budget from the seventh years (i.e., the benefit of the State subsidy for the promotion of renewable energies). In a general case, since BIPV systems operate 8 hours a day, it can contribute directly to the electricity economic that can be stored and can be also injected to public networks to distribute the surplus energies.

\section{References}

[1] Aguacil Moreno, S., Lufkin, S., \& Rey, E. (2017, juillet 4). Integrated design strategies for renovation projects with Building- Integrated Photovoltaics towards Low-Carbon Buildings: Two comparative case studies in Neuchâtel (Switzerland).

[2] Attoye, D., Adekunle, T., Tabet Aoul, K., Hassan, A., \& Attoye, S. (2018). A Conceptual Framework for a Building Integrated Photovoltaics (BIPV) Educative-Communication Approach. Sustainability, $10(10), 3781$. https://doi.org/10.3390/su10103781

[3] Baljit, S. S. S., Chan, H.-Y., \& Sopian, K. (2016). Review of building integrated applications of photovoltaic and solar thermal systems. Journal of Cleaner Production, 137, 677-689. https://doi.org/10.1016/j.jclepro.2016.07.150

[4] Ballif, C., Perret-Aebi, L.-E., Lufkin, S., \& Rey, E. (2018). Integrated thinking for photovoltaics in buildings. Nature Energy, 3(6), 438. https://doi.org/10.1038/s41560-018-0176-2

[5] Bamisile, O., Olubiyo, F., Dagbasi, M., Adun, H., \& Wole-Osho, I. (2019). Economic Analysis and Performance of PV 


\author{
(online) $=$ ISSN $2285-3642$ \\ ISSN-L = $2285-3642$ \\ Journal of Economic Development, Environment and People \\ Volume 9, Issue 1, 2020 \\ URL: http://jedep.spiruharet.ro \\ e-mail: office jedep@spiruharet.ro
}

[6] Plants: An Application in Kurdistan Region of Iraq. International Journal of Renewable Energy Development, 8(3), 293. https://doi.org/10.14710/ijred.8.3.293-301

[7] Bonomo, P., Chatzipanagi, A., \& Frontini, F. (2015). Overview and analysis of current BIPV products : New criteria for supporting the technological transfer in the building sector. VITRUVIO - International Journal of Architectural Technology and Sustainability, 0(1), 67-85. https://doi.org/10.4995/vitruvio-ijats.2015.4476

[8] Brito, M. C., Freitas, S., Guimarães, S., Catita, C., \& Redweik, P. (2017). The importance of facades for the solar PV potential of a Mediterranean city using LiDAR data. Renewable Energy, 111, 85-94. https://doi.org/10.1016/j.renene.2017.03.085

[9] Buonomano, A., Forzano, C., Kalogirou, S. A., \& Palombo, A. (2019). Building-façade integrated solar thermal collectors : Energy-economic performance and indoor comfort simulation model of a water based prototype for heating, cooling, and DHW production. Renewable Energy, 137, 20-36. https://doi.org/10.1016/j.renene.2018.01.059

[10] Chan, A. L. S. (2018). Evaluating the impact of photovoltaic systems on the thermal performance of buildings and its implication to building energy code. A case study in subtropical Hong Kong. Energy Policy, 119, 674-688. https://doi.org/10.1016/j.enpol.2018.04.041

[11] Dabaieh, M., \& Elbably, A. (2015). Ventilated Trombe wall as a passive solar heating and cooling retrofitting approach; a low-tech design for off-grid settlements in semi-arid climates. Solar Energy, 122, 820-833. https://doi.org/10.1016/j.solener.2015.10.005

[12] Delisle, V., \& Kummert, M. (2016). Cost-benefit analysis of integrating BIPV-T air systems into energy-efficient homes. Solar Energy, 136, 385-400. https://doi.org/10.1016/j.solener.2016.07.005

[13] Do, S. L., Shin, M., Baltazar, J.-C., \& Kim, J. (2017). Energy benefits from semi-transparent BIPV window and daylightdimming systems for IECC code-compliance residential buildings in hot and humid climates. Solar Energy, 155, 291-303. https://doi.org/10.1016/j.solener.2017.06.039

[14] Eicker, U. (2014). Energy efficient buildings with solar and geothermal resources.

[15] Gholami, H., Røstvik, H. N., \& Müller-Eie, D. (2019). Holistic economic analysis of building integrated photovoltaics (BIPV) system: Case studies evaluation. Energy and Buildings, 203, 109461. https://doi.org/10.1016/j.enbuild.2019.109461

[16] Ghosh, A., Sarmah, N., Sundaram, S., \& Mallick, T. K. (2019). Numerical studies of thermal comfort for semitransparent building integrated photovoltaic (BIPV)-vacuum glazing system. Solar Energy, 190, 608-616. https://doi.org/10.1016/j.solener.2019.08.049

[17] Hassanien, R. H. E., Li, M., \& Yin, F. (2018). The integration of semi-transparent photovoltaics on greenhouse roof for energy and plant production. Renewable Energy, 121, 377-388. https://doi.org/10.1016/j.renene.2018.01.044

[18] Hestnes, A. G. (1999). Building Integration Of Solar Energy Systems. Solar Energy, 67(4), 181-187. https://doi.org/10.1016/S0038-092X(00)00065-7

[19] Jelle, B. P. (2016). Building Integrated Photovoltaics: A Concise Description of the Current State of the Art and Possible Research Pathways. Energies, 9(1), 21. https://doi.org/10.3390/en9010021

[20] Jelle, B. P., Breivik, C., \& Røkenes, H. D. (2012). Building Integrated Photovoltaic Products: A State-of-the-Art Review and Future Research Opportunities. 69-96. https://doi.org/10.1016/j.solmat.2011.12.016

[21] Kamel, R., Ekrami, N., Dash, P., Fung, A., \& Hailu, G. (2015). BIPV/T+ASHP: Technologies for NZEBs. Energy Procedia, 78, 424-429. https://doi.org/10.1016/j.egypro.2015.11.687

[22] Kendirli, S., Unal, G., \& Basaran, M. S. (2014). Sustainable Environment and in the Context of Environment Economy Necessary and an Analyze. Journal of Economic Development, Environment and People, 3(4), 5-14. https://doi.org/10.26458/jedep.v3i4.87

[23] Lamy, M.-L. (2004). Efficacité des politiques environnementales d'incitation à l'adoption de nouvelles techniques : Le cas des énergies renouvelables (Thèse de doctorat). Université Pierre Mendès France, Grenoble, France.

[24] Lewis, N. S., \& Nocera, D. G. (2006). Powering the planet: Chemical challenges in solar energy utilization. Proceedings of the National Academy of Sciences of the United States of America, 103(43), 15729-15735. https://doi.org/10.1073/pnas.0603395103

[25] Majid, L. H. (2019). Giving a Chance to the Green Energy to Save our Planet Future. Journal of Economic Development, Environment and People, 8(3), 60-66. https://doi.org/10.26458/jedep.v8i3.636 
(online) $=$ ISSN $2285-3642$

ISSN-L = $2285-3642$

Journal of Economic Development, Environment and People

Volume 9, Issue 1, 2020

URL: http://jedep.spiruharet.ro

e-mail: office jedep@spiruharet.ro

[26] Martin Chivelet, N., Carlos Gutiérrez, J., Alonso Abella, M., Chenlo, F., \& Cuenca, J. (2018). Building Retrofit with Photovoltaics : Construction and Performance of a BIPV Ventilated Façade. Energies, 11. https://doi.org/10.3390/en11071719

[27] Ministère de l’Énergie-Algérie-Potentiels des Energies renouvelables. (s. d.). Consulté 20 juin 2019, à l'adresse http://www.energy.gov.dz/francais/index.php?page=potentiels

[28] Ng, P. K., \& Mithraratne, N. (2014). Lifetime performance of semi-transparent building-integrated photovoltaic (BIPV) glazing systems in the tropics. Renewable and Sustainable Energy Reviews, 31, 736-745. https://doi.org/10.1016/j.rser.2013.12.044

[29] Osseweijer, F. J. W., van den Hurk, L. B. P., Teunissen, E. J. H. M., \& van Sark, W. G. J. H. M. (2018). A comparative review of building integrated photovoltaics ecosystems in selected European countries. Renewable and Sustainable Energy Reviews, 90, 1027-1040. https://doi.org/10.1016/j.rser.2018.03.001

[30] Park, J., Hengevoss, D., \& Wittkopf, S. (2019). Industrial Data-Based Life Cycle Assessment of Architecturally Integrated Glass-Glass Photovoltaics. Buildings, 9(1), 8. https://doi.org/10.3390/buildings9010008

[31] Peng, C., Huang, Y., \& Wu, Z. (2011). Building-integrated photovoltaics (BIPV) in architectural design in China. Energy and Buildings, 43(12), 3592-3598. https://doi.org/10.1016/j.enbuild.2011.09.032

[31] Sánchez-Pantoja, N., Vidal, R., \& Pastor, M. C. (2018). Aesthetic perception of photovoltaic integration within new proposals for ecological architecture. Sustainable Cities and Society, 39, $203-214$. https://doi.org/10.1016/j.scs.2018.02.027

[32] Schuetze, T. (2013). Integration of Photovoltaics in Buildings-Support Policies Addressing Technical and Formal Aspects. Energies, 6(6), 2982-3001. https://doi.org/10.3390/en6062982

[33] Shirazi, A. M., Zomorodian, Z. S., \& Tahsildoost, M. (2019). Techno-economic BIPV evaluation method in urban areas. Renewable Energy, 143, 1235-1246. https://doi.org/10.1016/j.renene.2019.05.105

[34] Shukla, A. K., Sudhakar, K., Baredar, P., \& Mamat, R. (2018). BIPV based sustainable building in South Asian countries. Solar Energy, 170, 1162-1170. https://doi.org/10.1016/j.solener.2018.06.026

[35] Solangi, K. H., Islam, M. R., Saidur, R., Rahim, N. A., \& Fayaz, H. (2011). A review on global solar energy policy. Renewable and Sustainable Energy Reviews, 15(4), 2149-2163. https://doi.org/10.1016/j.rser.2011.01.007

[36] Tian, H., Zhang, W., Xie, L., Wu, Y., Sun, Y., Chen, M., ... Wu, X. (2018). Study on the Energy Saving Potential for SemiTransparent PV Window in Southwest China. Energies, 11(11), 3239. https://doi.org/10.3390/en11113239

[37] Tripathy, M., \& Sadhu, P. (2015). Building Integrated Photovoltaic Market trend and its Applications. TELKOMNIKA Indonesian Journal of Electrical Engineering, 14. https://doi.org/10.11591/telkomnika.v14i2.7338

[38] Wilson, R., \& Young, A. (1996). The embodied energy payback period of photovoltaic installations applied to buildings in the U.K. Building and Environment, 31(4), 299-305. https://doi.org/10.1016/0360-1323(95)00053-4

[39] Xu, X., Feng, G., Chi, D., Liu, M., \& Dou, B. (2018). Optimization of Performance Parameter Design and Energy Use Prediction for Nearly Zero Energy Buildings. Energies, 11, 3252. https://doi.org/10.3390/en11123252

[40] Yang, R. J., \& Zou, P. X. W. (2016). Building integrated photovoltaics (BIPV): Costs, benefits, risks, barriers and improvement strategy. International Journal of Construction Management, 16(1), 39-53. https://doi.org/10.1080/15623599.2015.1117709

[41] Zhang, T., Wang, M., \& Yang, H. (2018). A Review of the Energy Performance and Life-Cycle Assessment of BuildingIntegrated Photovoltaic (BIPV) Systems. Energies, 11(11), 3157. https://doi.org/10.3390/en11113157 